\title{
Identification and Characterization of Tomato Mutants Affected in the $R x$-Mediated Resistance to PVX Isolates
}

\author{
Bénédicte Sturbois, ${ }^{1}$ Marie-Pierre Dubrana-Ourabah, ${ }^{2}$ Julie Gombert, ${ }^{1}$ Bertrand Lasseur, ${ }^{1}$ \\ Audrey Macquet, ${ }^{1}$ Chantal Faure,${ }^{2}$ Abdelhafid Bendahmane, ${ }^{1}$ Isabelle Baurès, ${ }^{1}$ and Thierry Candresse ${ }^{1}$ \\ ${ }^{1}$ URGV, Unité de Recherche en Génomique Végétale, Université d’Evry Val d'Essonne, INRA, 2 rue Gaston Crémieux CP \\ 5708, 91057 EVRY cedex, France; ${ }^{2}$ Equipe de Virologie, INRA, UMR 1332 Biologie du Fruit et Pathologie, BP81, 33883 \\ Villenave d'Ornon cedex, France
}

Submitted 3 July 2011. Accepted 6 November 2011.

Five tomato mutants affected in the $R x$-mediated resistance against Potato virus $X(\mathbf{P V X})$ were identified by screening a mutagenized population derived from a transgenic, $R x 1$ expressing 'Micro-Tom' line. Contrary to their parental line, they failed to develop lethal systemic necrosis upon infection with the virulent PVX-KH2 isolate. Sequence analysis and quantitative reverse-transcription polymerase chain reaction experiments indicated that the mutants are not affected in the RxI transgene or in the Hsp90, RanGap1 and RanGap2, Rar1 and Sgt1 genes. Inoculation with the PVX-CP4 avirulent isolate demonstrated that the $R x 1$ resistance was still effective in the mutants. In contrast, the virulent PVX-KH2 isolate accumulation was readily detectable in all mutants, which could further be separated in two groups depending on their ability to restrict the accumulation of PVX-RR, a mutant affected at two key positions for $R x 1$ elicitor activity. Finally, transient expression of the viral capsid protein elicitor indicated that the various mutants have retained the ability to mount an $R x I$-mediated hypersensitive response. Taken together, the results obtained are consistent with a modification of the specificity or intensity of the $R x 1$-mediated response. The five Micro-Tom mutants should provide very valuable resources for the identification of novel tomato genes affecting the functioning of the $R x$ gene.

In nature, plants are continually challenged by various pathogens, including viruses, and, therefore, are equipped with a range of defense mechanisms. Some of these are constitutive barriers to pathogen entry or spread while others rely on the specific recognition of pathogens and on the induction of a wide array of defense responses (Chisholm et al. 2006; Dangl and Jones 2001; Jones and Takemoto 2004). Resistance genes

J. Gombert, B. Lasseur, and A. Macquet contributed equally to the manuscript.

Current address for J. Gombert: FAMS, Impasse du Verger, 49800 Brain sur l'Authion, France.

Current address for Isabelle Baurès: UMR Interactions Biotiques et Santé Végétale, INRA-CNRS, Université de Nice Sophia Antipolis, 400 route des Chappes, 06903 Sophia Antipolis, France.

Corresponding author: B. Sturbois; Telephone: +33-1-60-87-45-01; Fax: +33-1-60-87-45-10; E-mail: sturbois@evry.inra.fr

* The $e$-Xtra logo stands for "electronic extra" and indicates that four supplementary figures, one supplementary table, and additional materials and methods information is published online.
( $R$ genes) are central components of this surveillance system that perceives pathogens and induces cell defenses. Plant genomes contain hundreds of $R$ genes with different recognition specificities which confer resistance to many pathogens, including viruses (Collier and Moffett 2009; Martin et al. 2003).

In plants, resistance proteins have been grouped in different classes (Dangl and Jones 2001; Mac Dowell and Woffenden 2003; Martin et al. 2003), the largest of which encodes the socalled nucleotide-binding site leucine-rich repeat (NBS-LRR) type of R proteins (Eitas and Dangl 2010; Elmore et al. 2011; Kohler et al. 2008; Meyers et al. 2003; Monosi et al. 2004; Yang et al. 2008). So far, the majority of the identified $R$ genes conferring resistance to viruses belong to this type. NBS-LRR proteins can be further subdivided based on the presence of domains similar to a coil-coil domain (CC) or to a Toll and interleukin-1 receptor-like domain (TIR) (Ellis et al. 2000; Jones and Jones 1997; Nimchuk et al. 2003; Young 2000).

The NBS domain is involved in the binding of ATP and can act as a molecular switch, through conformational changes dependent of nucleotide-binding status (Collier and Moffett 2009; Moffett et al. 2002; Takken and Tameling 2009; Tameling et al. 2002). This NBS domain can trigger defense signaling when expressed in the absence of the other R protein domains (Collier and Moffett 2009; Rairdan et al. 2008; Takken and Tameling 2009). The LRR domain can confer pathogen recognition specificity and can also act as a positive or negative regulator (Collier and Moffett 2009; McHale et al. 2006; Takken and Tameling 2009; Tamura and Tachida 2011) even if other domains can also play a role in recognition specificity (Mackey et al. 2002; Mucyn et al. 2006). Physical interactions between the different domains of the NBS-LRR proteins are at the core of the protein activation (Lukasik and Takken, 2009; Moffet et al. 2002; Takken et al. 2006; Van Ooijen et al. 2007).

From the genetic point of view, the host-pathogen recognition process has been described by the gene-for-gene model, in which the recognition by a host dominant $R$ gene of a matching avirulence (Avr) determinant gene in the pathogen triggers the induction of the defense mechanisms (Flor 1971). However, only a limited number of direct interactions between $\mathrm{R}$ and Avr proteins have been revealed (Deslandes et al. 2003; Dodds et al. 2006; Ellis et al. 2007; Feys et al. 2001; Jia et al. 2000; Ueda et al. 2006). This has led to the development of the indirect or guard hypothesis, in which the $\mathrm{R}$ protein acts as part of a multiprotein recognition complex that initiates a signaling cascade after sensing a perturbation caused by the Avr protein (Dangl and Jones 2001; Innes 2004; Jones and Dangl 2006; Van der Biezen and Jones 1998; Van der Hoorn and Kamoun 2008). Examples of this guard model have been 
described for resistance against Pseudomonas syringae or Xanthomonas campestris in Arabidopsis thaliana (Belkhadir et al. 2004; Hou et al. 2009; Mackey et al. 2002; Rong et al. 2010) or against Fusarium oxysporum in tomato (Rep et al. 2004, 2005). A hybrid model between the direct and the indirect ones has also been proposed (Collier and Moffet 2009), in which the accessory proteins serve as baits and will interact with the Avr factor before interacting directly with the NBSLRR proteins. The dynamic nature of NB-LRR localization to different subcellular compartments before and after activation suggests that these proteins may activate immune responses in multiple compartments of the cell (Elmore et al. 2011).

The dominant gene $R x$ encodes a CC-NBS-LRR type of resistance protein and confers race-specific resistance against Potato virus X (PVX, Potexvirus) (Cockeram 1970). At least two orthologs with similar recognition specificities, $R x l$ and $R x 2$, have been identified, originating from two different wild Solanum spp. (Bendahmane et al. 1999, 2000; Ritter et al. 1991). Among the $R$ genes targeting viruses, the resistance conferred by $R x$, known as extreme resistance (ER), is quite unusual (Bendahmane et al. 1995; Kohm et al. 1993; Tozzini et al. 1991) because recognition of an avirulent PVX isolate induces a nonspecific antiviral mechanism which efficiently blocks PVX replication at a very early phase (Bendahmane et al. 1995; Kohm et al. 1993). This response also includes specific inhibition of viral RNA translation via Argonaute-like proteins (Bhattacharjee et al. 2009). Moreover, although elicitation of $R x$ is capable under some conditions of triggering the characteristic hypersensitive reaction (HR) linked to more typical $R$ genes (Heath 2000; Whitham et al. 1994), no HR is generally observed during PVX-Rx interactions (Bendahmane et al. 1999, 2000). In fact, HR is only observed when the $R x$ function is weakened or when the elicitor is over-expressed, indicating that, in these conditions, $R x$ functioning is not different from that of other NBS-LRR genes (Bendahmane et al. 1999; Sacco et al. 2007; Tameling and Baulcombe 2007).

Several cellular genes, such as Sgtlb, Hsp90, or Rarl, are implicated not only in the $R x$-mediated resistance but also in the function of other NBS-LRR proteins (Azevedo et al. 2006; Peart et al. 2002; Shirasu 2009). These proteins are hypothesized to be part of a chaperone complex essential for NBSLRR protein folding and stability (Botër et al. 2007; Shirasu 2009). The RAR1 and SGT1 proteins have been shown to be associated with the LRR domain of R proteins; for example, in the case of MLA in barley (Bieri et al. 2004). Concerning their subcellular localization, SGT1 is localized in both the cytoplasm and the nucleus (Noël et al. 2007) and HSP90 seems to play a role in the shuttling between these two compartments (Tago et al. 2004). Different studies have also led to the identification of a RanGTPase-activating protein, RanGap2, that is required for Rxl function (Sacco et al. 2007; Tameling and Baulcombe 2007). RanGap proteins are essential proteins in eukaryotic cells for the regulation of nucleo-cytoplasmic trafficking (Meier 2007; Meier and Brkljacic 2009a and b; Pay et al. 2002; $\mathrm{Xu}$ et al. 2007).

The virus recognized by $R x, \mathrm{PVX}$, is a widespread pathogen of potato and the type member of the genus Potexvirus (family Alphaflexiviridae) of plus-stranded RNA viruses (Adams et al. 2004; Batten et al. 2003; Martelli et al. 2007; Verchot-Lubicz et al. 2007). Among the five proteins encoded by the capped and polyadenylated genome, the capsid protein (CP) is encoded by the $3^{\prime}$-most open reading frame (ORF5) and is required for virus replication, cell-to-cell movement and encapsidation (Atabekov et al. 2001; Chapman et al. 1992; Cruz et al. 1998; Karpova et al. 2006; Lukashina et al. 2009; VerchotLubicz et al. 2007; Zayakina et al. 2008). Reverse genetics and transient expression experiments have shown the $\mathrm{CP}$ to be the elicitor recognized by the $R x$ machinery (Bendahmane et al. 1995; Goulden and Baulcombe 1993; Goulden et al. 1993; Kavanagh et al. 1992; Kohm et al. 1993). A fragment of approximately 110 amino acids of the PVX CP is sufficient to trigger the resistance reaction (Baurès et al. 2008).

The threonine at position 121 of the $\mathrm{CP}$ is crucial for avirulence toward $R x$ because a change into a lysine, as in the PVX HB isolate, abolished the recognition by potato genotypes carrying $R x$ (Goulden and Baulcombe 1993; Goulden et al. 1993; Querci et al. 1993). The amino acid in position 127 of the CP also plays an important role in the fitness of variants containing the $\mathrm{T} 121 \mathrm{~K}$ resistance-breaking mutation (Goulden et al. 1993). However, the behavior of PVX mutants affected at these two positions in transgenic $R x$-expressing Nicotiana benthamiana plants has shown that the specificity of the $R x$ gene could be subtly affected by the genetic context in which the $R x$ resistance gene is expressed (Baurès et al. 2008).

Tomato (Solanum lycopersicum), a biologically and molecularly well-known Solanaceae crop, is widely grown around the world and constitutes the second most consumed vegetable after potato. Tomato is the centerpiece for genetic and plant molecular research for the family Solanacae, due to its biological and genetic characteristics and to the availability of rich genetic and genomic resources (Ashrafi et al. 2009; Barone et al. 2009; D'Agostino et al. 2009; Emmanuel and Levy 2002; Fei et al. 2011; Fernandez et al. 2009; Foolad 2007; JiménezGomez and Maloof 2009; Labate et al. 2009; Shirasawa et al. 2010a and b; Tanksley 1993). A pre-release of the tomato genome shotgun sequence is already available (Mueller et al. 2009). In tomato, approximately 200 diseases and 110 pathogen species have been described (Gottula and Fuchs 2009; Lukyanenko 1991) and this plant has proven to be very useful for the study of plant-pathogen molecular interactions.

'Micro-Tom', a dwarf tomato cultivar allowing high-density cultivation, is a valuable model plant representative of the Solanaceae and other crop families with berry-type fruit (Marti et al. 2006) for which wide genetic and genomic resources are available (Aoki et al. 2010; Dan et al. 2006; Matsukura et al. 2008; Ozaki et al. 2010; Saito et al. 2011; Shirasawa et al. 2010a and b). Inoculation of Micro-Tom plants with 16 different pathogens (fungus, bacteria, and virus) has shown Micro-Tom to be a valuable model for plant-pathogen interaction studies (Takahashi et al. 2005). In addition, previous experiments have demonstrated the proper functioning of the $R x l$ gene expressed in transgenic Micro-Tom tomato (Candresse et al. 2009).

To provide more information about the molecular mechanisms and host genes implicated in the functioning of the $R x$ based virus resistance, transgenic Micro-Tom plants expressing a functional potato $R x l$ gene have been subjected to chemical mutagenesis, and more than 2,000 F2 families have been screened for altered interaction with a partially avirulent PVX isolate (PVX-KH2). Five F2 families with an altered inter-

Table 1. Number and proportion of plants in F2 progenies from crosses between the various mutants surviving Potato virus $X$ (PVX)-KH2 inoculation (mutant phenotype $)^{\mathrm{a}}$

\begin{tabular}{lcccc}
\hline & \multicolumn{4}{c}{ Proportion (\%) } \\
\cline { 2 - 5 } Line & $\mathbf{3 4 6 7}$ & $\mathbf{3 1 4 1}$ & $\mathbf{2 1 3 5}$ & $\mathbf{2 0 6 4}$ \\
\hline 1179 & $39 / 43(91)$ & $23 / 26(88)$ & $29 / 35(83)$ & $32 / 44(76)$ \\
2064 & $40 / 48(83)$ & $17 / 38(45)$ & $17 / 33(51)$ & na \\
2135 & $35 / 38(92)$ & $12 / 28(43)$ & na & na \\
3141 & $30 / 36(83)$ & na & na & na \\
\hline
\end{tabular}

a The number of plants without lethal necrosis surviving inoculation is given, together with the total number of inoculated plants. The identity of the parent crosses to obtain the tested progeny is given in the top row and left-most column; na = does not apply. 
action phenotype have been identified. This article presents the genetic and molecular characterizations of these five mutants. The results obtained indicate that these mutants have retained a normal expression of Rxl transgene and the ability to recognize a PVX avirulent isolate (PVX-CP4) but that they are affected in the specificity or intensity of their interaction with other PVX isolates. This study is the first step toward the positional cloning of the corresponding genes, which modulate the functioning of $R x 1$.

\section{RESULTS}

\section{Identification of mutagenized M2 $R x$ Micro-Tom tomato families showing an altered interaction phenotype with the partially avirulent PVX-KH2 isolate.}

Following the positional cloning of the $R x 1$ gene (Bendahmane et al. 1999), Agrobacterium spp.-mediated transformation using the pSLJ1 recombinant plasmid which carries $R x 1$ controlled by its own regulatory elements was used to obtain transgenic potato and $N$. benthamiana plants to validate its identification (Bendahmane et al. 1999). The same construct was also used to obtain transgenic Rxl-expressing tomato plants (Micro-Tom). Like their $N$. benthamiana and potato counterparts, the $R x 1$-expressing Micro-Tom plants show resistance toward the avirulent PVX-CP4 isolate (discussed below). One of the fixed T2 progenies (R7-Rx\#11) derived from the R7-Rx line, which contains a single copy of the transgene as judged by Southern blotting experiments (not shown), was subjected to ethyl-methane-sulfonate (EMS) mutagenesis following the procedure of Meissner and associates (1997). In total, 4,480 mutagenized seeds germinated and were transferred to the greenhouse, and variable numbers of seeds could be obtained for 2,186 of these M1 plants.

With the objective to identify cellular genes that might affect the functioning of $R x 1$, the M2 families thus obtained were screened for the ability to survive the $R x l$-dependent lethal necrosis observed in their parental R7-Rx\#11 line upon inoculation of the PVX-KH2 partially avirulent isolate (Fig. 1), a recombinant strain carrying the virulent $\mathrm{PVX}-\mathrm{HB}$ coat protein in the avirulent PVX-CP4 background. In total, young plants from 1,945 M2 families were inoculated (average 12.1 plants/family) by agroinfiltrating their cotyledons with recombinant Agrobacterium cells carrying the pG101 binary construct, which harbors a full-length infectious cDNA of PVX$\mathrm{KH} 2$ under the control of the Cauliflower mosaic virus (CaMV) 35S promoter.

Plants surviving this first round of screening were kept, and produced progenies were then similarly inoculated in order to validate the mutant phenotype and identify progenies in which the mutant trait was fixed. In this way, five mutant lines (line numbers $1179,2064,2135,3141$, and 3467 ) were finally obtained, which reproducibly survived the inoculation of the PVX-KH2 isolate and showed no necrotic symptoms or only few and very limited necrotic spots (Fig. 1). These lines had otherwise unremarkable phenotypes, with the exception of line number 3141 , which showed a stunted and chlorotic, lightergreen phenotype.

\section{Genetic characterization of the five Micro-Tom mutant lines showing modified interaction with PVX-KH2.}

Allelism tests were performed by crossing each of the five mutants with the other four and submitting the F2 progenies derived from these crosses to the PVX-KH2 inoculation assay. In all F2 progenies, plants showing lethal necrosis symptoms typical of the unmutated R7-Rx\#11 parental line were observed. In contrast, no segregation of the mutant phenotype was ever observed in progenies derived from the various fixed mutants by selfing. Therefore, these results indicated that the mutations harbored by the different mutants were not allelic and corresponded to mutations affecting different genes.

However, the expected percentage of mutant compared with parental phenotype in an F2 population obtained by crossing two mutants carrying independent recessive mutations is $44 \%$. Such a rate of mutant versus parental phenotype was observed for a few crosses (lines $2064 \times 3141,2064 \times 2135$, and $2064 \times$ $3141)$ and a $\chi^{2}$ test validated at the $5 \%$ level the hypothesis of two independently segregating recessive genes. For all other crosses, however, a significant excess of plants surviving PVX-KH2 inoculation was observed (Table 1), with some F2 populations showing 80 to $90 \%$ of plants that did not develop the systemic lethal necrosis typical of the R7-Rx\#11 parental line. In all cases, the hypothesis of independently segregating recessive genes was rejected by a $\chi^{2}$ test but, conversely, the hypothesis that these crosses involved at least one dominant gene was validated at the 5\% level. All these crosses implicated either mutant 1179 or mutant 3467 as one of the parents, an observation which is paralleled by the fact that, upon testing F1 plants derived from the $1179 \times \mathrm{R} 7-\mathrm{Rx} \# 11$ cross, no plants with the parental phenotype were observed (result not shown). A similar test could not be performed for mutant 3467 because too few F1 seeds were obtained. Therefore, these results prompted an evaluation of the dominance status of the mutations carried by the various mutants.

Each mutant was crossed with the parental R7-Rx\#11 line and F1 and F2 populations were obtained. Two contrasting situations were observed upon inoculation of the F2 populations with the PVX-KH2 isolate. For mutants 2064, 2135, and 3141 , a low proportion of the F2 populations showed the mutant phenotype, with the associated absence of lethal systemic necrosis: $18 \%$ (7/39 inoculated plants), $8 \%$ (4/51), and $16 \%$ $(3 / 19)$, respectively. Such percentages are compatible with the $25 \%$ rate expected for recessive mutations, and this hypothesis was validated by $\chi^{2}$ tests at the $5 \%$ level for mutants 2064 and 3141. In contrast, for mutants 1179 and 3467, the proportions were reversed, with a high frequency of plants showing the mutant phenotype upon PVX-KH2 inoculation: $73 \%$ (35/48) and $83 \%$ (29/35), respectively. In this case, the segregation rate was close to the $75 \%$ rate expected for dominant mutations, and this scenario was validated by $\chi^{2}$ tests at the $5 \%$ level.

\section{Characterization of the $R x I$ transgene and of genes known to be required for $R x I$ functioning in the various Micro-Tom mutants.}

To evaluate whether the five identified mutants could be affected either in the Rxl transgene or in genes known to be required for $R x l$ functioning, the mRNAs or the genomic DNA for Rxl and for Hsp90, RanGap1, RanGap2, Rarl, and Sgt1b (Azevedo et al. 2006; Sacco et al. 2007; Shirasu 2009; Tameling and Baulcombe, 2007) were amplified in all five mutants and in the parental R7-Rx\#11 line used as a control. Sequencing of all amplification products failed to provide evidence for the presence of mutations in any of the analyzed genes in any of the mutants (data not shown). The possibility that mutations in the regulatory sequences (which had not been analyzed) of the studied genes may affect their expression was then evaluated by comparing the expression level of all six genes by semiquantitative reverse-transcriptase polymerase chain reaction (RTPCR) or by quantitative RT-PCR in all five mutants and in the parental transgenic line, R7-Rx\#11, used as a control (Fig. 2). As an additional control, the expression of the five cellular genes was also compared in nontransgenic Micro-Tom plants.

Concerning the $R x l$ transgene, its expression appeared to be unchanged in the different mutants, even if a statistically nonsignificant 1.5-fold expression increase was observed in mutant 


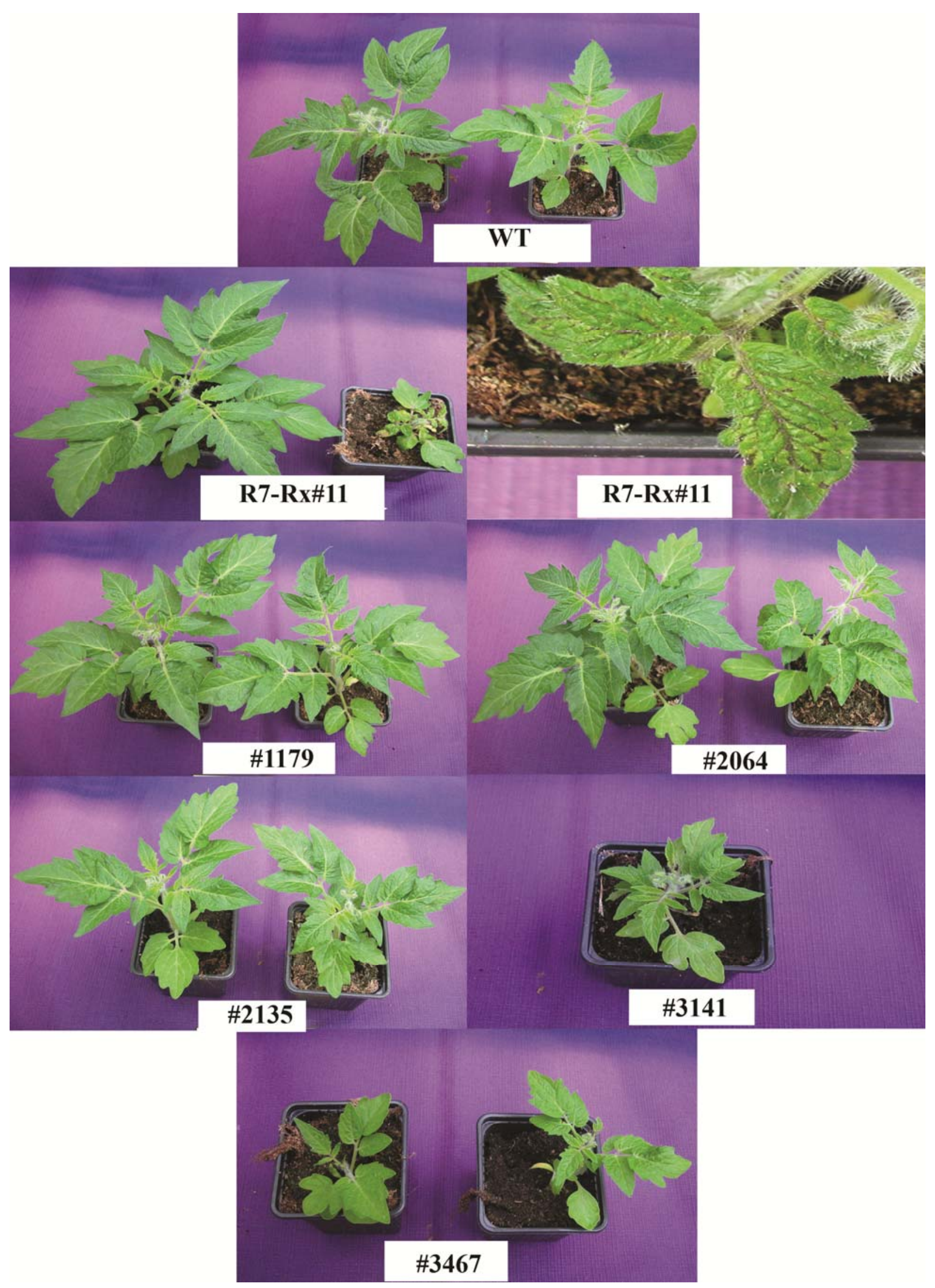

Fig. 1. Symptoms observed on upper, uninoculated leaves of the different 'Micro-Tom' lines (wild type [WT], Rxl-expressing parental transgenic line R7Rx\#11, and the five mutants derived from it: \#1179, \#2064, \#2135, \#3141, and \#3467) 21 days after inoculation or not of Potato virus X (PVX)-KH2. The plant on the left side is an uninoculated control and the plant of the right side was inoculated with the PVX-KH2 strain, except for the mutant 3141 , for which only the inoculated plant is represented. For the R7-Rx\#11 line, a close-up of the leaves of inoculated plant showing necrosis is presented in the right picture. 
3141 (Fig. 2). Given the very low concentration of the Rx protein in plants and the absence of $R x l$-specific antibodies, it was not possible to evaluate whether the unmodified $R x I$ mRNAs expression in the mutants was paralleled by a similar unmodified accumulation of the Rx1 protein.

All five cellular genes analyzed by quantitative RT-PCR could be readily amplified, and few statistically significant changes in expression levels could be observed by comparing the mutant lines and the control plants. All detected differences were limited in amplitude, being less than twofold (Fig. 3). Mutant 3467 showed slightly reduced expression of both Sgt1 and Rarl genes while mutant 3141 showed limited reductions in expression of Rarl and RanGapl genes. In addition, expression of the RanGap2 gene appeared slightly reduced in mutant 2064 but slightly increased in mutant 1179 . All other comparisons fell within the statistically explained variability of the experiments (Fig. 3).

\section{Detailed phenotypic analysis of the interaction} between the mutants and PVX isolates.

The various mutants were separately inoculated with three PVX isolates: the avirulent CP4 isolate, the partially avirulent
$\mathrm{KH} 2$ isolate, and the CP4-RR isolate with mutations in the two amino acids positions (121 and 127) identified as critical for $R x l$ recognition. In previous experiments, the CP4-RR isolate has shown an $R x l$-dependent restriction in inoculated leaves after inoculation in transgenic $N$. benthamiana plants (Baurès et al. 2008). The parental R7-Rx\#11 line and nontransgenic Micro-Tom plants were inoculated in parallel as controls.

Upon inoculation with PVX-CP4, symptoms in the form of mild mottling or mosaic were only observed in the untransformed Micro-Tom control plants. All the other tested plants failed to develop any symptoms (Supplementary Fig. 1). Western blotting analysis using anti-PVX antibodies failed to detect significant PVX accumulation in all inoculated plants, with the exception of the untransformed Micro-Tom controls, in which PVX CP could be readily detected (Fig. 4A). Semiquantitative RT-PCR amplification of the viral CP gene was performed in upper, noninoculated leaves 2 weeks after inoculation (Fig. 4A; Table 2). Again, viral accumulation was readily detectable in the untransformed Micro-Tom controls. A very low level of accumulation could be detected in the parental R7-Rx\#11 plants but no accumulation could be detected in any of the tested mutants. These results indicate that limited replication
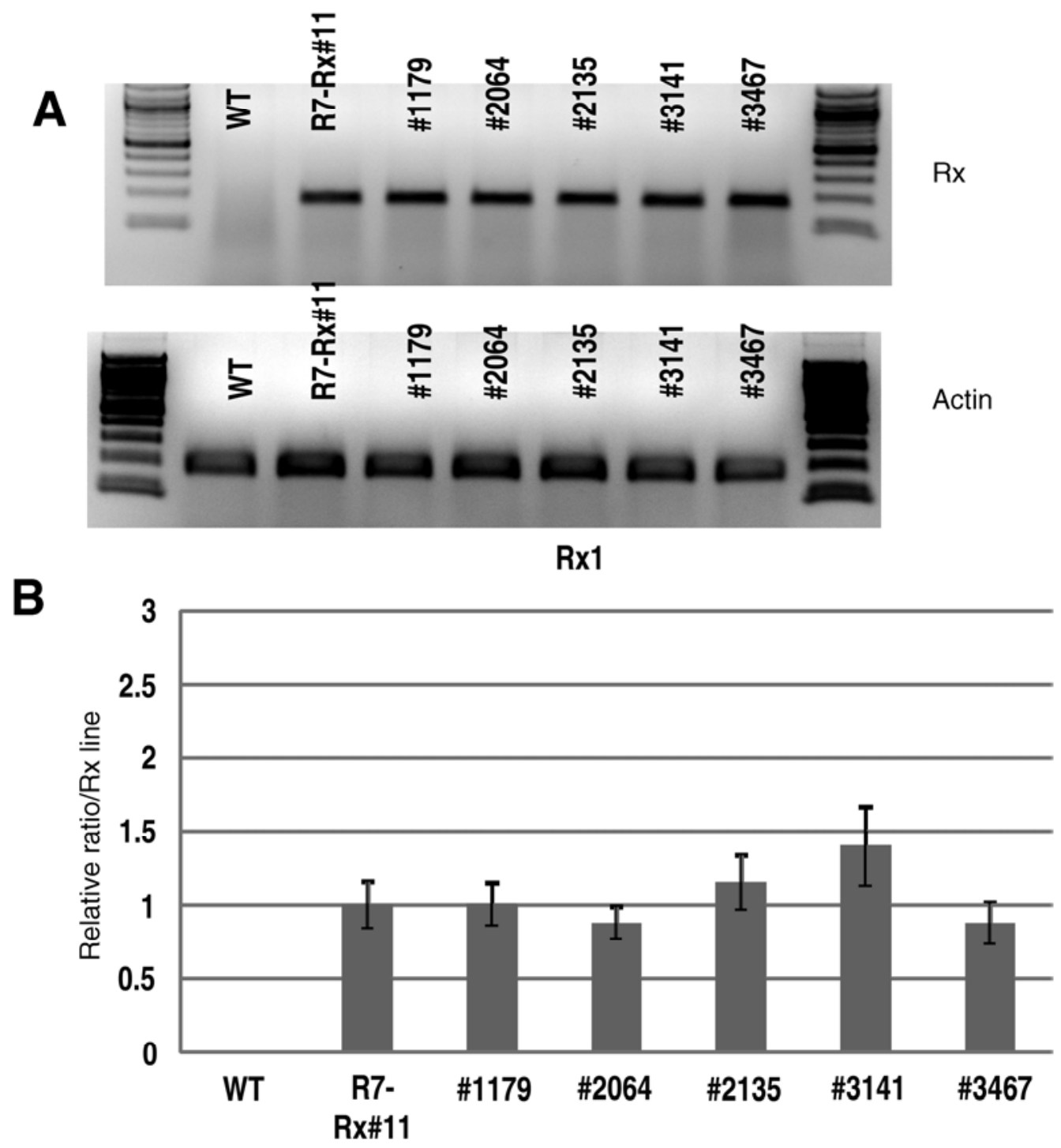

Fig. 2. Expression of the $R x 1$ transgene in the different 'Micro-Tom' lines analyzed by A, reverse-transcription polymerase chain reaction (PCR) or B, quantitative PCR. For quantitative PCR, the quantification of gene expression was performed using the comparative cycle threshold number (Ct) method. Ct values for the different genes were normalized to the $\mathrm{Ct}$ value of the two reference genes. For each gene, the expression in the Micro-Tom mutant lines (\#1179, \#2064, \#2135,\#3141, and \#3467) was compared with the expression in the parental R7-Rx\#11 line and a relative ratio was calculated. 
and movement of PVX-CP4 occurs in the Rxl-expressing parental Micro-Tom line. The same observations have been made after inoculation of PVX-CP4 on Rxl-expressing transgenic $N$. benthamiana plants (Supplementary Fig. 2).

The inoculation of the partially avirulent PVX-KH2 isolate resulted in the expected systemic necrosis symptoms on the $R x 1$-expressing R7-Rx\#11 parental line. Because this necrosis is $R x l$ dependent, it was not observed in the nontransgenic control plants. As expected, it was not observed either in any of the mutants which showed only very mild symptoms. Western blot analysis revealed PVX CP accumulation in all tested plants and the viral RNA was similarly detected by RT-PCR in the upper, noninoculated leaves of all tested plants (Fig. 4B; Table 2; Supplementary Fig. 4).

Upon inoculation with the mutant CP4-RR isolate, two distinct phenotypes could be observed. The nontransformed MicroTom plants, together with mutant lines 1179 and 3467, showed distinct mottle or mosaic symptoms, accompanied by readily detectable PVX CP and RNA accumulation in the upper uninoculated leaves of the plants (Fig. 4C; Table 2). In contrast, the inoculated R7-Rx\#11 plants and those of mutants 2064, 2135, and
3141 failed to show distinct PVX symptoms, and no PVX CP accumulation could be detected by western blot (Fig. 4C; Table 2). RT-PCR analysis provided evidence for limited accumulation of the PVX RNA in the R7-Rx\#11 plants and in mutant 2135 but no viral RNA was detected in the other two mutants.

To rule out the possibility of the appearance of resistancebreaking variants upon propagation in the various tested lines or mutants, the entire coat protein gene of progeny viruses was amplified and sequenced. This confirmed the stability of the introduced mutations because no evidence for the accumulation of additional mutations or of reversion of the introduced mutations was observed (data not shown).

\section{The mutants have retained the ability to develop an $R x 1$-mediated HR.}

Because the most striking property of the mutants is the failure to develop an Rxl-dependent systemic necrosis upon inoculation of the partially avirulent PVX-KH2 isolate, their ability to develop an Rxl-mediated HR was then evaluated. This was performed by transient expression, through agroinfiltration, of the avirulent $\mathrm{CP} 4 \mathrm{CP}$ in leaves of the various mutants and of
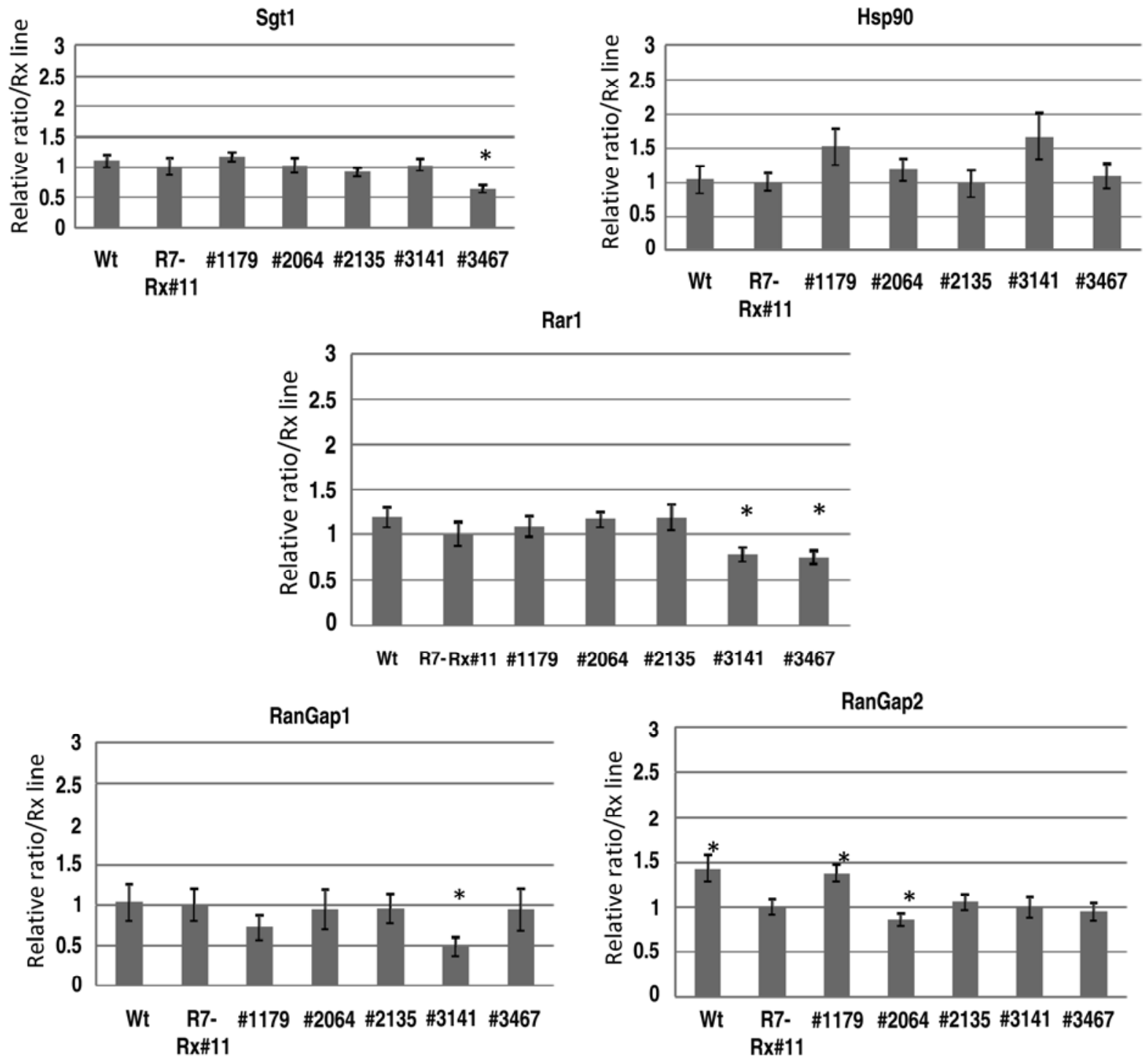

Fig. 3. Expression of the Sgt1b, Hsp 90, Rar1, RanGap1, and RanGap2 genes in the different 'Micro-Tom' lines analyzed by quantitative polymerase chain reaction. The quantification of gene expression was performed using the comparative cycle threshold number (Ct) method. Ct values for the different genes were normalized to the Ct value of the two reference genes. Gene expression in the Micro-Tom mutant lines (\#1179, \#2064, \#2135, \#3141, and \#3467) was compared with the expression of the same gene in the Rxl-expressing parental R7-Rx\#11 line and a relative ratio was calculated. An asterisk (*) indicates statistically significant difference at the $P<0.05$ level as estimated by a one-way analysis of variance. 
control plants. As controls, leaves were also infiltrated with Agrobacterium cells carrying a binary vector driving the expression of the $\mathrm{CP}$ of PVX-KH2 (identical to that of the virulent PVX-HB isolate) or of Agrobacterium cells driving the expression of the $\beta$-glucuronidase (GUS) reporter gene. Using the parental R7-Rx\#11 line, the leaf area infiltrated with the $\mathrm{CP} 4$-expressing construct developed a local necrotic reaction within a few days. This was not observed in leaf areas infiltrated with either the agrobacteria driving the expression of the PVX-KH2 CP or those driving the expression of the control GUS reporter control (Fig. 5; Table 2). In parallel tests, no HR was observed following infiltration of any of the three bacterial cultures assayed in the nontransgenic Micro-Tom control plants (Fig. 5; Table 2). The behavior of all five mutants fully paralleled that of their parental R7-Rx\#11 line, indicating that

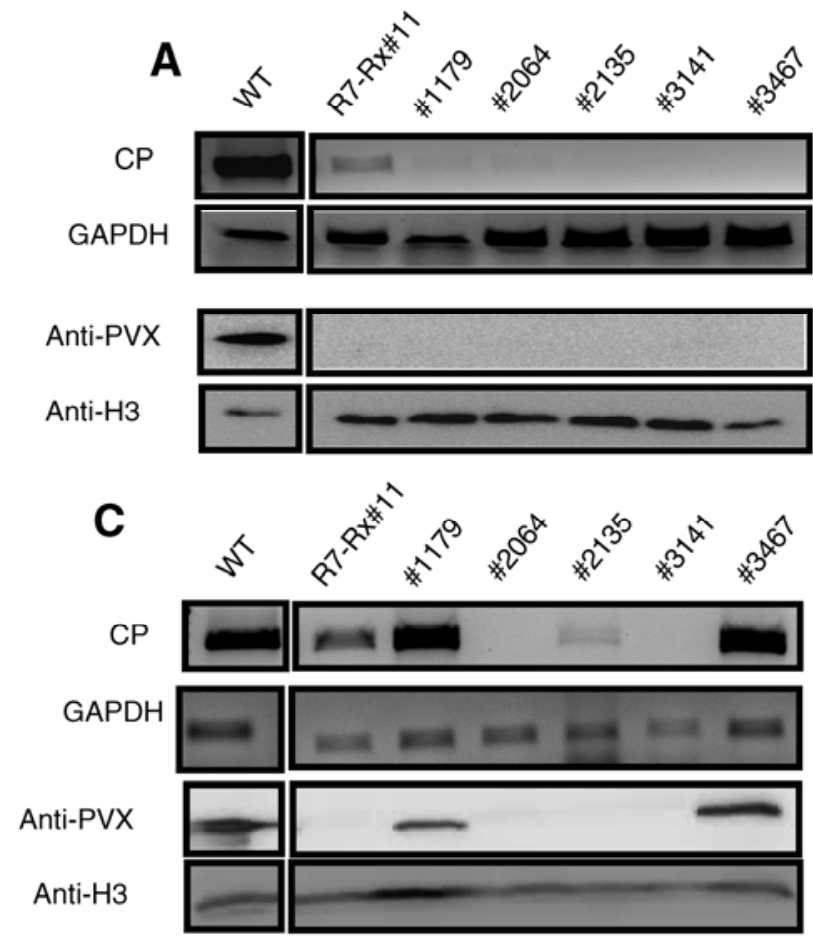

all mutants had retained the ability to mount a localized HR reaction upon transient expression of the PVX-CP4 CP but that no HR was observed with the PVX-KH2 CP.

On the other hand, infiltration of the leaves of the mutants with agrobacteria driving the expression of the CP4-RR CP separated them into two groups. Mutants 1179 and 3467 behaved like the wild-type Micro-Tom and did not develop a HR, whereas mutants 2064 and 2135 together with the parental R7Rx\#11 line showed a distinct HR reaction in the infiltrated leaf areas (Table 2; Supplementary Fig. 3).

\section{DISCUSSION}

The results presented here provide a detailed characterization of the phenotype of the parental R7-Rx\#11 transgenic tomato

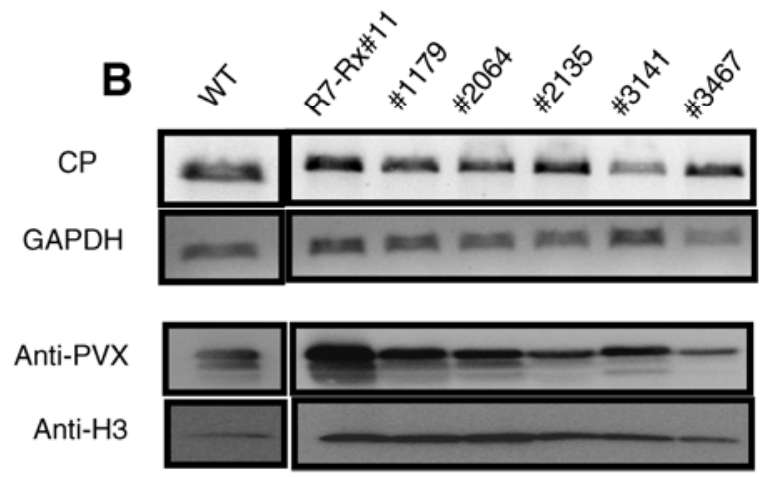

Fig. 4. Potato virus $X(\mathrm{PVX})$ RNA and capsid protein (CP) accumulations in upper uninoculated leaves of the various 'Micro'-Tom lines, as revealed by reverse-transcription polymerase chain reaction (RT-PCR) and Western blot analyses, respectively. The PVX isolates used were A, PVX-CP4; B, PVX-KH2; and C, PVX-CP4-RR. The GAPDH mRNA and Histone H3 (H3) were used as internal controls for RT-PCR and Western blot analyses, respectively. Twentyfive cycles of amplification were used for the RT-PCR experiments. The tissues from the same set of experiment (PVX-CP4, PVX-KH2, and PVX-RR) were harvested 21 days after inoculation.

Table 2. Systemic response characterized by the presence (+) or absence (-) of symptoms, Potato virus $X$ (PVX) RNA accumulation, and PVX capsid protein $(\mathrm{CP})$ accumulation observed 21 days after inoculation of various PVX isolates on cotyledons of wild-type (WT) 'Micro-Tom', transgenic Rxlexpressing Micro-Tom parental line R7-Rx\#11, and various mutants derived from it (line numbers 1179, 2064, 2135, 3141, and 3467) ${ }^{\mathrm{a}}$

\begin{tabular}{|c|c|c|c|c|c|c|c|c|}
\hline Response & Isolate & WT & R7-Rx\#11 & 1179 & 2064 & 2135 & 3141 & 3467 \\
\hline \multirow{3}{*}{ Symptoms } & PVX-CP4 & + & - & - & - & - & - & - \\
\hline & PVX-KH2 & + & +++ & \pm & \pm & \pm & \pm & \pm \\
\hline & PVX-RR & + & - & + & - & - & - & + \\
\hline \multirow[t]{3}{*}{ Virus accumulation } & PVX-CP4 & ++ & \pm & - & - & - & - & - \\
\hline & PVX-KH2 & + & ++ & + & + & + & \pm & + \\
\hline & PVX-RR & ++ & + & ++ & - & \pm & - & ++ \\
\hline \multirow[t]{3}{*}{ Protein accumulation } & PVX-CP4 & + & - & - & - & - & - & - \\
\hline & PVX-KH2 & + & ++ & + & + & + & + & + \\
\hline & PVX-RR & ++ & - & + & - & - & - & + \\
\hline \multirow[t]{3}{*}{$\mathrm{CP}$ induced $\mathrm{HR}$} & PVX-CP4 & - & + & + & + & + & + & + \\
\hline & PVX-KH2 & - & - & - & - & - & - & - \\
\hline & PVX-RR & - & + & - & + & + & ND & - \\
\hline
\end{tabular}

${ }^{a}$ Symptoms include mottle, mosaic, or necrosis. PVX RNA and CP accumulations were revealed by reverse-transcription polymerase chain reaction and Western-blot, respectively. The presence (+) or absence (-) of a localized hypersensitive reaction (HR) upon transient expression by agroinfiltration of the $\mathrm{CP}$ of the various isolates is also indicated; $+++=$ lethal systemic necrosis; $\pm=$ limited mosaic/mottle symptoms occasionally accompanied with erratic necrotic spots; and ND = not determined. 

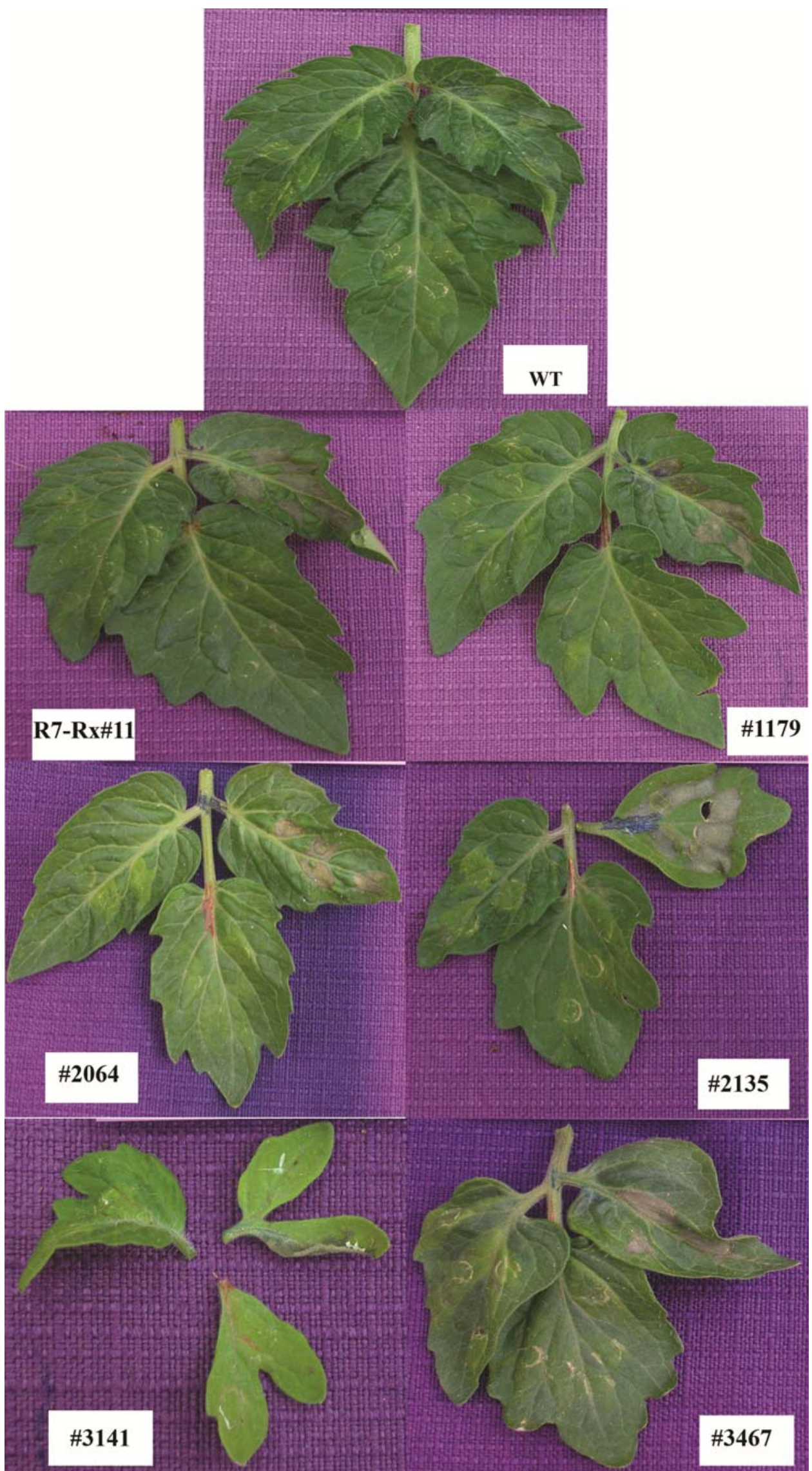

Fig. 5. Symptoms observed on the leaves of the various 'Micro-Tom' lines upon Agrobacterium spp.-mediated transient expression of the coat protein of Potato virus $X$ (PVX)-CP4 or PVX-KH2 or the control (pGreen-GUS). The leaf on the right side was agroinfiltrated with the PVX-CP4 construct. The leaf on the left side was agroinfiltrated with the PVX-KH2 construct. The leaf in the center was agroinfiltrated with the control plasmid (pGreen-GUS). The symptoms were observed 4 to 5 days after agroinfiltration. 
line. As compared with $R x$ potato plants, in which accumulation of avirulent PVX isolates is reported to be undetectable in intact plants or in protoplast a few hours after inoculation due to the extreme resistance phenotype (Bendahmane et al. 1999, 2000), low but reproducible accumulation of PVX-CP4 RNA was detected by RT-PCR in inoculated (not shown) and noninoculated upper leaves of R7-Rx\#11 plants (Fig. 4A; Table 2). However, no $\mathrm{CP}$ of the same avirulent isolate could be detected by Western blotting (Fig. 4A; Table 2), suggesting a very low level of PVX-CP4 accumulation. The difference in the sensitivity of the two detection techniques used probably explains why low-level accumulation of PVX RNA is sometimes observed in the apparent absence of PVX CP accumulation. As compared with untransformed Micro-Tom plants, PVX-CP4 accumulation detected in noninoculated R7-Rx\#11 leaves is much reduced, as shown by the absence of symptomatology, the failure to detect the viral CP by Western blotting, and the lower viral RNA accumulation as judged by semiquantitative RT-PCR analysis (Fig. 4A, comparison between the wild type and R7-Rx\#11 line). A similar reduced but not abolished infection phenotype was observed in transgenic $N$. benthamiana plants transformed with the same construct. Similarly, both transgenic tomato and $N$. benthamiana plants showed the $R x$ dependent ability to mount a local HR upon transient expression of the CP4 CP (Baurès et al. 2008) (Fig. 5; Table 2), the known elicitor of $R x$. Overall, these results indicate that, even if the resistance against PVX is conferred by the transgene used, this resistance might be influenced in various ways by some regulatory elements or by positional insertion effects of the transgene in the host genome. Upon chemical mutagenesis of the R7-Rx\#11 line and screening of close to 2,000 M2 populations, five mutants were obtained which no longer showed the $R x 1$-mediated lethal systemic necrosis observed in the parental line upon inoculation of the partially avirulent PVX-KH2 isolate (Fig. 1). Genetic characterization showed all five mutants to be independent and, therefore, affected in different genes (Table 1). The mutations carried by two mutants, 1179 and 3467, appear to be dominant. This observation is both surprising, because loss-of-function recessive mutations are mostly expected upon screening of mutagenized M2 populations, and interesting, because very few dominant mutations affecting the functioning of $R$ genes or their downstream signaling are known to date; as, for example, for extracellular receptor (Jaillais et al. 2011). Most of the dominant mutations characterized so far in $R$ genes or in other genes involved in resistance to various pathogens result in constitutive resistance (Bendhamane et al. 2002; Rathjen et al. 1999; Zhang et al. 2003).

Several hypotheses could explain the phenotypes and the molecular results obtained for the five mutants (Table 2). The most trivial one, a mutation affecting the $R x l$ transgene, has been ruled out by the absence of mutation in the transgene sequence for the five mutants (results not shown) and by the unchanged $R x l$-expression in the various mutants compared with the R7-Rx\#11 line (Fig. 2). Because no specific antibody against the $\mathrm{Rx} 1$ protein is available, the potential consequence of the various mutations on $\mathrm{Rx} 1$ protein accumulation cannot be analyzed. However, the Rx1 protein seems to be functional in the five mutants because they have retained the ability to resist PVX-CP4 infection and to mount an $\mathrm{HR}$ in reaction to the transient expression of its CP (Figs. 4 and 5; Table 2).

Other hypotheses that could explain the observed PVX-KH2 infection phenotype of the mutants include (i) an inability to support PVX replication or (ii) an inability to mount an HR upon recognition of the PVX CP elicitor. Hypothesis (i) can be ruled out by the observation of the significant accumulation of PVX-KH2 mRNA and coat protein in both inoculated (data not shown) and uninoculated tissues of the various mutants (Fig. 4B; Table 2). Although, in the experiments presented in Figure 4B, the accumulation level of PVX-KH2 appears somewhat reduced in some mutants compared with the parental R7Rx\#11 line, more closely matched accumulation levels have been observed in some other experiments; therefore, this difference is unlikely to be responsible for the large difference in infection phenotype observed but more likely reflects the difficulties inherent in the comparison of viral accumulation in normal tissues or in tissues undergoing lethal necrosis.

Hypothesis (ii) can also be eliminated, this time by the results obtained upon transient expression of the PVX-CP4 CP in leaves of the various mutants (Fig. 5; Table 2). Indeed, despite the fact that Agrobacterium spp. transient expression experiments proved to be quite difficult to perform in MicroTom leaves, all mutants appeared to be able to develop an Rxlmediated HR similar to the one observed in the parental line.

It is also possible that two independent pathways may coexist downstream of the Rx-mediated recognition event, one leading to Rxl-mediated resistance and HR and one leading to systemic lethal necrosis. This could explain why the lethal necrosis reaction is affected in the mutants whereas neither the Rxl-mediated resistance nor the Rx1-mediated HR is compromised. However, the existence of such an independent mechanism has never been demonstrated.

The last hypothesis that could explain the phenotype of the mutants upon inoculation with PVX-KH2 is that the affected genes modulate either the recognition specificity or the intensity of the reaction triggered by the $R x$ machinery. In this scenario, both the parental Micro-Tom and the mutants would efficiently recognize the avirulent PVX-CP4 CP, leading to efficient resistance (Fig. 4; Table 2), but the recognition of PVX-KH2 would be differentially affected, leading to the absence of the Rxl-mediated systemic necrosis reaction to PVXKH2 inoculation in the mutants (Fig. 1; Table 2). Although both the parent R7-Rx\#11 line and the mutants did not develop an HR upon PVX-KH2 CP transient expression (Fig. 5; Table $2)$, the systemic necrosis observed in R7-Rx\#11 is unambiguously $R x l$ dependent. This suggests the existence of a residual interaction between the PVX-KH2 CP and the $R x 1$ machinery in line R7-Rx\#11, which could be affected in the mutant lines. The hypothesis of a modified recognition specificity or intensity is supported by the observation that the five mutants could be classified in two quite different interaction phenotypes when confronted with the CP4-RR mutant isolate that carries an elicitor of an intermediate activity between $\mathrm{KH} 2$ and $\mathrm{CP} 4$ (Fig. 4C; Table 2). The results obtained after inoculation of the PVX RR strain on the Rxl-expressing Micro-Tom R7-Rx\#11 line are significantly different from previous results observed on Rxl-expressing N. benthamiana plants (Baurès et al. 2008), for which local lesion were observed on inoculated leaves but no viral RNA or CP accumulation in upper, uninoculated leaves was detected by RT-PCR or by Western blotting, respectively. These results suggest that the interaction outcome could potentially be influenced by the genetic background in which the $R x l$ gene is expressed (Micro-Tom tomato versus Nicotiana spp.) or by transgene integration or expression effects. This raises the possibility that the specificity or intensity of recognition of the PVX CP could be modulated by host factors. The same kind of scenario has been proposed to explain differences in interaction phenotype after PVX inoculation between $R x$ potato and $R x l$-expressing transgenic Nicotiana plants (Baurès et al. 2008). The different hosts presented in those studies (potato, Nicotiana spp., and now Micro-Tom tomato) have in common the expression of the same resistance gene, $R x l$, but in a different cellular background. Taken together, these observations reinforce the hypothesis that host genes 
could influence specifically the intensity or specificity of the Rx-mediated response to particular PVX isolates.

The possibility that the genes affected in the various mutants could correspond to one of the currently known host genes needed for $R x$ functioning, accumulation, degradation, or subcellular localization (as, for example, Sgt1, Hsp90, RanGapl, RanGap2, and Rarl) (Azavedo et al. 2002, 2006; Slootweg et al. 2010; Tameling et al. 2010) seems quite unlikely given the absence of mutation in these genes in the mutants and the very limited transcript accumulation differences observed for these genes (Fig. 3).

The five mutants reported here should provide a valuable resource for the identification of further cellular genes needed for the efficient functioning of $R x$ and possibly of other $R$ genes through positional cloning or other strategies.

\section{MATERIALS AND METHODS}

\section{Plant materials.}

A transgenic line (R7-Rx\#11) of Micro-Tom tomato containing a single $R x l$ transgene under its own promoter was used in this study (A. Bendahmane, unpublished). The plants were obtained by Agrobacterium spp.-mediated transformation using the pSLJ1 recombinant plasmid (Bendahmane et al. 1999), which was initially used to obtain transgenic potato and $N$. benthamiana plants to validate the identification of $R x$ (Bendahmane et al. 1999). Nontransgenic Micro-Tom plants were used as controls when needed. All plants were grown in greenhouses with controlled temperature $\left(24^{\circ} \mathrm{C}\right.$ during the day and $19^{\circ} \mathrm{C}$ during the night) and light $(16 \mathrm{~h} /$ day $)$.

\section{EMS mutagenesis of the R7-Rx\#11 Micro-Tom line.}

In total, 35,000 seeds of the R7-Rx\#11 line were subjected to EMS mutagenesis following the procedure of Meissner and associates (1997), with incubation in the presence of $1 \%$ EMS for $17 \mathrm{~h}$. Following this treatment, 4,480 seeds germinated and produced plants that were transferred to a greenhouse. In total, M2 progenies composed of a variable number of seeds could be obtained for 2,186 of these M1 plants.

\section{Virus isolates and inoculation assays.}

The PVX isolates used in this study were maintained in wildtype $N$. benthamiana plants. The isolates used were the avirulent CP4 isolate (GenBank AF172259), the virulent HB isolate (GenBank X72214), the partially virulent $\mathrm{KH} 2$ isolate (a recombinant derived from $\mathrm{CP} 4$ but carrying a $\mathrm{CP}$ sequence derived from $\mathrm{HB}$ ), and the RR mutant derived from $\mathrm{CP} 4$ and carrying threonine to arginine and lysine to arginine mutations at amino acids 121 and 127, respectively, of the $C P$ (Baurès et al. 2008). To carry out the $R x$ resistance assays, each virus was mechanically inoculated to wild-type or $R x$-expressing plants by rubbing both cotyledons at the two- to four-leaf stage with $20 \mu \mathrm{l}$ of infected plant extract in the presence of Carborundum (400 mesh) used as abrasive. Extracts were prepared by grinding with sand one leaf of an infected $N$. benthamiana plant in $4 \mathrm{ml}$ of $10 \mathrm{mM}$ sodium phosphate buffer ( $\mathrm{pH} 7$ ) and clarifying the homogenate by centrifugation for $2 \mathrm{~min}$ at 2,000 rpm before use. The inoculated plants were scored for symptoms of viral infection between 14 to 21 days after inoculation. The presence of virus in noninoculated upper leaves was verified by RT-PCR using primers designed to amplify the viral coat proteins as well as by Western blotting, using specific anti-PVX antibodies.

\section{Screening of the M2 mutagenized families} for altered $\boldsymbol{R} \boldsymbol{x}$-mediated response.

The M2 mutagenized families were inoculated with the partially avirulent PVX-KH2 isolate, which causes mild mottling symptoms in nontransgenic Micro-Tom control plants but causes an $R x$-mediated lethal systemic necrosis in the parental R7-Rx\#11 line. Whenever possible, 16 to 20 individual plants were inoculated for each M2 family but, for some families, a lower number of plants was used due to low seed-set or to low germination rate of the mutagenized families. Inoculation was performed by agroinfiltration (Bendahmane et al. 2000) using C58C1 Agrobacterium cells containing a binary vector harboring a full-length infectious cDNA of PVX-KH2 under the control of the CaMV $35 \mathrm{~S}$ promoter.

\section{RNA isolation.}

Total RNAs were extracted from frozen, inoculated tomato leaves using the Trizol reagent (Invitrogen, Cergy Pointoise, France) according to the protocol described by Devic and associates (1989). The quality of each RNA extract was checked by $1 \%$ agarose gel electrophoresis. Contaminating DNA was removed by DNaseI treatment (Invitrogen). Total RNA $(20 \mu \mathrm{g})$ was treated at $37^{\circ} \mathrm{C}$ for $60 \mathrm{~min}$ in a total volume of $100 \mu \mathrm{l} \mathrm{con-}$ taining 7.5 U of DNAse I and $25 \mathrm{U}$ of RNAseOUT (Promega, Charbonnières, France). Following a phenol/chloroform extraction, nucleic acids were precipitated with $300 \mu \mathrm{l}$ of $100 \%$ ethanol and $15 \mu \mathrm{l}$ of $\mathrm{NaAc}(3 \mathrm{M}, \mathrm{pH} 5.5)$. The final pellet was washed with $70 \%$ ethanol, dried, and resuspended in $30 \mu \mathrm{l}$ of diethylpyrocarbonate water. The efficiency of the DNase treatment was validated by PCR using oligonucleotides specific for DNA unspliced form of the tomato phospho-glycerate kinase (PGK) gene (TC203809) and tomato genomic DNA as positive amplification control.

\section{Reverse transcription of the viral coat protein and of cellular SGT1, HSP90, RanGap1 and RanGap2, Rar 1, and $R x 1$ transcripts.}

Total RNA $(2 \mu \mathrm{g})$ was used for the first-strand cDNA synthesis, which was primed with $0.02 \mathrm{pmol}$ of oligo $\mathrm{dT}_{20}(0.6 \mu \mathrm{l})$ (Invitrogen) in the case of the cellular transcripts or with the reverse PCR primer in the case of the viral CP gene. This mixture $(11.5 \mu \mathrm{l})$ was heated at $70^{\circ} \mathrm{C}$ for $10 \mathrm{~min}$ and then cooled on ice for $5 \mathrm{~min}$. The reaction mix was completed at $20 \mu \mathrm{l}$ by adding $4 \mu \mathrm{l}$ of $5 \times$ Superscript buffer (Invitrogen), $2 \mu \mathrm{l}$ of 100 $\mathrm{mM}$ dithiothreitol (DTT) (Invitrogen), $1 \mu \mathrm{l}$ of $5 \mathrm{mM}$ of $\mathrm{dNTP}$, and $0.5 \mu \mathrm{l}(40 \mathrm{U})$ of RNaseOUT (Invitrogen) and was incubated at $37^{\circ} \mathrm{C}$ for $5 \mathrm{~min}$ before adding $100 \mathrm{U}$ of Superscript III reverse transcriptase (Invitrogen). The reaction was incubated at $37^{\circ} \mathrm{C}$ for $2 \mathrm{~h}$. The first-strand cDNA was converted into double-strand DNA by PCR. All RT-PCR tests were performed with the oligonucleotides described in Supplementary Table 1, using 25 cycles of amplification and $1 \mu$ of the RT reaction, $0.2 \mathrm{mM}$ dNTP, $0.4 \mu \mathrm{M}$ each primer, and $1.25 \mathrm{U}$ of Taq polymerase (Biolabs, Evry, France). Cycling conditions were as follows: $94^{\circ} \mathrm{C}$ for $10 \mathrm{~min} ; 25$ cycles of $95^{\circ} \mathrm{C}$ for $10 \mathrm{~s}, 55^{\circ} \mathrm{C}$ for $15 \mathrm{~s}$, and $72^{\circ} \mathrm{C}$ for $1 \mathrm{~min}$; and a final extension of $5 \mathrm{~min}$ at $72^{\circ} \mathrm{C}$. The identity of all PCR products was checked by direct sequencing allowing, in the case of the PVX CP products, validation of the stability of the viral isolates used upon propagation in the various tomato lines.

\section{Evaluation of viral accumulation using semiquantitative PCR.}

The accumulation of the various PVX isolates in the different Micro-Tom lines was analyzed by semiquantitative RTPCR using total RNA extracts prepared as described above. To verify that all samples showed similar concentration and amplification efficiency, first-strand cDNAs obtained as described above were first subjected to duplicate amplification with primers specific for the housekeeping GAPDH gene. PCR amplification was conducted in a $25-\mu$ l reaction volume contain- 
ing $1 \mu \mathrm{g}$ of cDNA, $1.25 \mathrm{U}$ of Taq polymerase (Biolabs), 0.2 $\mathrm{mM}$ dNTP, and $0.4 \mu \mathrm{M}$ each primer. Amplification cycles were as follows: $94^{\circ} \mathrm{C}$ for $3 \mathrm{~min} ; 25$ cycles of $94^{\circ} \mathrm{C}$ for $30 \mathrm{~s}, 62^{\circ} \mathrm{C}$ for $30 \mathrm{~s}$, and $72^{\circ} \mathrm{C}$ for $1 \mathrm{~min}$; and a final extension at $72^{\circ} \mathrm{C}$ for $5 \mathrm{~min}$. Amplification products were analyzed by nondenaturing $1 \%$ agarose gel electrophoresis. Ethidium bromide-stained amplification products were visualized under UV illumination and images of the gels were acquired with the Kodak 1D Image Analysis Software, allowing quantification of the GAPDH target, which was used to normalize results for the amplified viral coat protein gene amplified as described above but using a $50-\mu$ reaction volume.

\section{Analysis of cellular genes expression using quantitative PCR.}

Real-time RT-PCR assays were performed in an optical 384well plate with an ABI PRISM 7900 HT Sequence Detection System (Applied Biosystems, Carlsbad, CA, U.S.A.), using qPCR MasterMix Plus for SYBR Green I w/o UNG (Eurogentec, Angers, France) and according to the manufacturer's instructions. Specific primer sets were designed to amplify a small sequence fragment of the Rxl, RanGap2, Sgt1, Hsp90, and Rarl tomato cDNAs. The quality and identity of all PCR products were validated by gel electrophoresis and direct sequencing. A standard amplification curve was generated from triplicate series of five DNA template dilutions to test PCR efficiencies. All PCR reactions were conducted in triplicate in the presence of $1 \mathrm{ng}$ of cDNA, $3 \mu \mathrm{l}$ of primer mix ( $1 \mu \mathrm{M}$ each), and $2.5 \mu$ of Mesa GREEN qPCR Mastermix Plus for SYBR Green I w/o UNG (Eurogentec) in a 10- $\mu$ l final reaction volume. The PCR conditions were $10 \mathrm{~min}$ at $95^{\circ} \mathrm{C}$; then, $40 \mathrm{cy}$ cles $\left(10 \mathrm{~s}\right.$ at $95^{\circ} \mathrm{C}$ and $10 \mathrm{~s}$ at $\left.60^{\circ} \mathrm{C}\right)$; then, $95^{\circ} \mathrm{C}$ for $15 \mathrm{~s}, 60^{\circ} \mathrm{C}$ for $15 \mathrm{~s}$, and $95^{\circ} \mathrm{C}$ for $15 \mathrm{~s}$. The results were standardized by comparing the data obtained for two housekeeping genes, $P P 2$ and $P G K$, that are often used as reference genes in tomato (Lovdal and Lillo 2009). PCR amplification specificity was verified by a dissociation curve $\left(55\right.$ to $\left.95^{\circ} \mathrm{C}\right)$. A negative control without cDNA, technical replicates on two independent cDNA samples (derived from the same RNA sample), and two independent biological experiments were performed in all cases. Data were analyzed using the SDS 2.0 software (Applied Biosystems). The quantification of gene expression was performed using the comparative cycle threshold number $(\mathrm{Ct})$ method. To compare data from different PCR runs and cDNA samples, $\mathrm{Ct}$ values for the different genes were normalized to the $\mathrm{Ct}$ value of the two reference genes. For each gene, the expression levels in each sample were calculated relative to the $R x$-expressing line, R7-Rx\#11, because the EMS mutants have been created in an $R x$-expressing background. A one-way analysis of variance was performed for each gene to detect a possible line effect.

\section{Western blot analysis of PVX CP accumulation.}

Upper, noninoculated leaves $(500 \mu \mathrm{g})$ were ground under liquid nitrogen and $500 \mu \mathrm{l}$ of $2 \times$ Laemmli solution ( $10 \%$ glycerol, 3\% sodium dodecyl sulfate [SDS], 0.2 M DTT, $0.004 \%$ bromophenol blue, $0.09 \%$ SDS, and $0.12 \mathrm{M}$ Tris $\mathrm{HCl}, \mathrm{pH}$ 6.8) were added. The samples were incubated at $100^{\circ} \mathrm{C}$ for $10 \mathrm{~min}$ and immediately placed on ice for $10 \mathrm{~min}$ before centrifugation for $10 \mathrm{~min}$ at $10,000 \times \mathrm{g}$. Samples were kept at $-20^{\circ} \mathrm{C}$ before use. Each sample $(12 \mu \mathrm{l})$ was loaded and separated on a $12 \%$ denaturing acrylamide gel and blotted on a polyvinylidene diflouride membrane (RPN303F; GE Healthcare, Munich, Germany). Incubations with the primary (immunoglobulin $\mathrm{G}$ [IgG] polyclonal antibody against PVX; DSMZ, Braunschweig, Germany) and secondary (peroxidase-conjugated goat anti-rabbit IgG; Sigma-Aldrich, Lyon, France) antibodies were performed as described previously (Baurès et al. 2008). After four washes of $10 \mathrm{~min}$ in TTBS (0.1 M Tris, $0.15 \mathrm{M} \mathrm{NaCl}$ [pH 7.5], and $0.1 \%$ Triton $\mathrm{X} 100$ ), the membrane was revealed with the Amersham ECL Plus Western blotting detection reagents kit (GE Healthcare). Blots were scanned with Gene Gnome system and Gene Snap software (Syngene Corporation, Cambridge, U.K.) with 1, 5, or $10 \mathrm{~min}$ of exposure.

The membranes were then stripped to remove the primary and secondary antibodies by incubation twice for $10 \mathrm{~min}$ in stripping buffer ( $1.5 \%$ glycine, $0.1 \%$ SDS, and $0.1 \%$ Tween 20 , $\mathrm{pH} 2.2$ ) and then incubated twice for $10 \mathrm{~min}$ in phosphatebuffered saline buffer $\left(8 \% \mathrm{NaCl}, 0.2 \% \mathrm{KCl}, 1.4 \% \mathrm{Na}_{2} \mathrm{HPO}_{4}\right.$, and $\left.24 \% \mathrm{KH}_{2} \mathrm{PO}_{4}, \mathrm{pH} 7.4\right)$. The membrane was then washed in TTBS, rehydrated for $1 \mathrm{~min}$ in methanol, and washed again in TTBS for 5 min, before a blocking step as described above. A detection of Histone $\mathrm{H} 3$ was then performed as a loading control, using the same technique as described above, except IgG polyclonal antibodies against Histone H3 (dilution 1/20,000; Abcam, Paris, France) as the primary antibodies.

\section{Transient expression of various forms of the PVX CP in the different Micro-Tom lines.}

The coat protein genes of the CP4 (avirulent, T121-K127), and the KH2 (virulent, K121-R127, similar to the PVX-HB CP) isolates of PVX were cloned in pBin61 vector (Bendahmane et al. 1999). Following sequence verification of the constructs, they were transferred to the Agrobacterium strain C58C1 (containing the virulence helper plasmid pCH32). The agroinfiltration protocol described by Bendahmane and associates (2000) was used for transient expression of the various PVX CP constructs in the leaves of young tomato plants. Agrobacterium cells carrying a vector allowing the expression of the GUS reporter gene were used as control. The symptoms have been observed 4 to 5 days after agroinfiltration.

\section{ACKNOWLEDGMENTS}

This work was partially supported by a grant from Génoplante, the French Plant Genomics initiative (CI 2000007). We thank T. Mauduit, M. Roncoroni, A. Bailly, P. Audigier, C. Lepage, and P. Grillot for taking excellent care of the plants; D. Baulcombe for $R x$ MicroTom transgenic line; W. Tameling for the very helpful discussions and for agroinfiltration trials; and M.-L. Martin-Magniette for the statistical analysis of the quantitative PCR results.

\section{LITERATURE CITED}

Adams, M. J., Antoniw, J. F., Bar-Joseph, M., Brunt, A. A., Candresse, T., Foster, G. D., Martelli, G. P., Milne, R. G., Zavriev, S. K., and Fauquet, C. M. 2004. The new plant virus family Flexiviridae and assessment of molecular criteria for species demarcation. Arch. Virol. 149:1045-1060.

Aoki, K., Yano, K., Suzuki, A., Kawamura, S., Sakurai, N., Suda, K., Kurabayashi, A., Suzuki, T., Tsugane, T., Watanabe, M., Ooga, K., Torii, M., Narita, T., Shin-I, T., Kohara, Y., Yamamoto, N., Takahashi, H., Watanabe, Y., Egusa, M., Kodama, M., Ichinose, Y., Kikuchi, M., Fukushima, S., Okabe, A., Arie, T., Sato, Y., Yazawa, K., Satoh, S., Omura, T., Ezura, H., and Shibata, D. 2010. Large-scale analysis of full-length cDNAs from the tomato (Solanum lycopersicum) cultivar Micro-Tom, a reference system for the Solanaceae genomics. BMC Genomics 11:210.

Ashrafi, H., Kinkade, M., and Foolad, M. R. 2009. A new genetic linkage map of tomato based on a Solanum lycopersicum $x$ S. pimpinellifolium RIL population displaying locations of candidate pathogen response genes. Genome 52:935-956.

Atabekov, J. G., Rodionova, N. P., Karpova, O. V., Kozlovsky, S. V., Novikov, V. K., and Arkhipenko, M. V. 2001. Translational activation of encapsidated potato virus $\mathrm{X}$ RNA by coat protein phosphorylation. Virology 286:466-474.

Azevedo, C., Sadanandom, A., Kitagawa, K., Freialdenhoven, A., Shirasu, K., Schulze-Lefert, P. 2002. The RAR1 interactor SGT1, an essential component of $R$ gene-triggered disease resistance. Science 295:20732076. 
Azevedo, C., Betsuyaku, S., Peart, J., Takahashi, A., Noel, L., Sadanandom, A., Casais, C., Parker, J., and Shirasu, K. 2006. Role of SGT1 in resistance protein accumulation in plant immunity. EMBO (Eur. Mol. Biol. Organ.) J. 25:2007-2016.

Barone, A., Di Matteo, A., Carputo, D., and Frusciante, L. 2009. Highthrough put genomics enhances tomato breeding efficiency. Curr. Genomics 10:1-9.

Batten, J. S., Yoshinari, S., and Hemenway, C. 2003. Potato virus X: A model system for virus replication, movement and gene expression. Mol. Plant Pathol. 4:125-131.

Baurès, I., Candresse, T., Leveau, A., Bendahmane, A., and Sturbois, B. 2008. The Rx gene confers resistance to a range of potexviruses in transgenic Nicotiana plants. Mol. Plant-Microbe Interact. 21:1154-1164

Belkhadir, Y., Nimchuk, Z., Hubert, D. A., Mackey, D., and Dangl, J.L. 2004. Arabidopsis RIN4 negatively regulates disease resistance mediated by RPS 2 and RPM1 downstream or independent of the NDR1 signal modulator and is not required for the virulence functions of bacterial type III effectors AvrRpt2 or AvrRpm1. Plant Cell 16:2822-2835.

Bendahmane, A., Kohm, B. A., Dedi, C., and Baulcombe, D. C. 1995. The coat protein of potato virus $\mathrm{X}$ is a strain-specific elicitor of Rx1-mediated virus resistance in potato. Plant J. 8:933-941.

Bendahmane, A., Kanyuka, K., and Baulcombe, D. C. 1999. The Rx gene from potato controls separate virus resistance and cell death responses. Plant Cell 11:781-792.

Bendahmane, A., Querci, M., Kanyuka, K., and Baulcombe, D. C. 2000 Agrobacterium transient expression system as a tool for the isolation of disease resistance genes: Application to the $\mathrm{Rx} 2$ locus in potato. Plant $\mathrm{J}$. 21:73-81.

Bendahmane, A., Farnham, G., Moffett, P., and Baulcombe, D. C. 2002 Constitutive gain-of-function mutants in a nucleotide binding site-leucine rich repeat protein encoded at the Rx locus of potato. Plant $\mathrm{J}$. 32:195-204.

Bhattacharjee, S., Zamora, A., Azhar, M. T., Sacco, M. A., Lambert, L. H., and Moffett, P. 2009. Virus resistance induced by NB-LRR proteins involves Argonaute4-dependent translational control. Plant J. 58:940-951.

Bieri, S., Mauch, S., Shen, Q. H., Peart, J., Devoto, A., Casais, C., Ceron, F., Schulze, S., Steinbiss, H. H., Shirasu, K., and Schulze-Lefert, P. 2004. RAR1 positively controls steady state levels of barley MLA resistance proteins and enables sufficient MLA6 accumulation for effective resistance. Plant Cell 16:3480-3495.

Botër, M., Amigues, B., Peart, J., Breuer, C., Kadota, Y., Casais, C., Moore, G., Kleanthous, C., Ochsenbein, F., Shirasu, K., and Guerois, R. 2007. Structural and functional analysis of SGT1 reveals that its interaction with HSP90 is required for the accumulation of $\mathrm{Rx}$, an $\mathrm{R}$ protein involved in plant immunity. Plant Cell 19:3791-3804.

Candresse, T., Marais, A., Faure, C., Dubrana, M. P., Gombert, J., and Bendahmane, A. 2009. Multiple coat protein mutations abolish recognition of Pepino mosaic potexvirus (PepMV) by the potato Rx resistance gene in transgenic tomatoes. Mol. Plant-Microbe Interact. 23:376-383.

Chapman, S., Hills, G., Watts, J., and Baulcombe, D. C. 1992. Mutational analysis of the coat protein gene of potato virus X: Effects on virion morphology and viral pathogenicity. Virology 191:223-230.

Chisholm, S. T., Coaker, G., Day, B., and Staskawicz, B. J. 2006. Hostmicrobe interactions: Shaping the evolution of the plant immune response. Cell 124:803-814.

Cockeram, G. 1970. Genetical studies on resistance to potato viruses $\mathrm{X}$ and Y. Heredity 25:309-348.

Collier, S. M., and Moffett, P. 2009. NB-LRRs work a "bait and switch" on pathogens. Trends Plant Sci. 14:521-529.

Cruz, S. S., Roberts, A. G., Prior, D. A., Chapman, S., and Oparka, K. J. 1998. Cell-to-cell and phloem-mediated transport of potato virus X. The role of virions. Plant Cell 10:495-510.

D’Agostino, N., Traini, A., Frusciante, L., and Chiusano, M. L. 2009. SolEST database: A "one-stop shop" approach to the study of Solanaceae transcriptomes. BMC Plant Biol. 9:142.

Dan, Y., Yan, H., Munyikwa, T., Dong, J., Zhang, Y., and Armstrong, C. L. 2006. MicroTom-a high-throughput model transformation system for functional genomics. Plant Cell Rep. 25:432-441.

Dangl, J. L., and Jones, J. D. 2001. Plant pathogens and integrated defence responses to infection. Nature 411:826-833.

Deslandes, L., Olivier, J., Peeters, N., Feng, D. X., Khounlotham, M., Boucher, C., Somssich, I., Genin, S., and Marco, Y. 2003. Physical interaction between RRS1-R, a protein conferring resistance to bacterial wilt, and PopP2, a type III effector targeted to the plant nucleus. Proc. Natl. Acad. Sci. U.S.A. 100:8024-8029.

Devic, M., Jaegle, M., and Baulcombe, D. 1989. Symptom production on tobacco and tomato is determined by two distinct domains of the satellite RNA of cucumber mosaic virus (strain Y). J. Gen. Virol. 70:2765-2774.

Dodds, P. N., Lawrence, G. J., Catanzariti, A. M., Teh, T., Wang, C. I., Ayliffe, M. A., Kobe, B., and Ellis, J. G. 2006. Direct protein interaction underlies gene-for-gene specificity and coevolution of the flax resistance genes and flax rust avirulence genes. Proc. Natl. Acad. Sci. U.S.A. 103:8888-8893.

Eitas, T. K., and Dangl, J. L. 2010. NB-LRR proteins: Pairs, pieces, perception, partners, and pathways. Curr. Opin. Plant Biol. 13:472-477.

Ellis, J. G., Dodds, P. N., and Pryor, T. 2000. Structure, function and evolution of plant disease resistance genes. Curr. Opin. Plant Biol. 3:278284.

Ellis, J. G., Dodds, P. N., and Lawrence, G. J. 2007. Flax rust resistance gene specificity is based on direct resistance-avirulence protein interactions. Annu. Rev. Phytopathol. 45:289-306.

Elmore, J. M., Lin, Z. J., and Coaker, G. 2011. Plant NB-LRR signaling: Upstreams and downstreams. Curr. Opin. Plant Biol. 14:1-7.

Emmanuel, E., and Levy, A. A. 2002. Tomato mutants as tools for functional genomics. Curr. Biol. 5:112-117.

Fei, Z., Joung, J. G., Tang, X., Zheng, Y., Huang, M., Lee, J. M., McQuinn, R., Tieman, D. M., Alba, R., Klee, H. J., and Giovannoni, J. J. 2011 Tomato functional genomics database: A comprehensive resource and analysis package for tomato functional genomics. Nucleic Acids Res. 39:D1156-1163.

Fernandez, A. I., Viron, N., Alhagdow, M., Karimi, M., Jones, M., Amsellem, Z., Sicard, A., Czerednik, A., Angenent, G., Grierson, D., May, S., Seymour, G., Eshed, Y., Lemaire-Chamley, M., Rothan, C. and Hilson, P. 2009. Flexible tools for gene expression and silencing in tomato. Plant Physiol. 151:1729-1740.

Feys, B. J., Moisan, L. J., Newman, M. A., and Parker, J. E. 2001. Direct interaction between the Arabidopsis disease resistance signaling proteins, EDS1 and PAD4. EMBO (Eur. Mol. Biol. Organ.) J. 20:54005411

Flor, H. H. 1971. Current status of the gene-for-gene concept. Annu. Rev. Phytopathol. 9:275-296.

Foolad, M. R. 2007. Genome mapping and molecular breeding of tomato. Int. J. Plant Genomics 64358. Published online.

Gottula, J., and Fuchs, M. 2009. Toward a quarter century of pathogen-derived resistance and practical approaches to plant virus disease control. Adv. Virus Res. 75:161-183.

Goulden, M. G., and Baulcombe, D. C. 1993. Functionally homologous host components recognize Potato virus $X$ in Gomphrena globosa and potato. Plant Cell 5:921-930.

Goulden, M. G., Kohm, B. A., Cruz, S. S., Kavanagh, T. A., and Baulcombe, D. C. 1993. A feature of the coat protein of potato virus X affects both induced virus resistance in potato and viral fitness. Virology 197:293302.

Heath, M. C. 2000. Hypersensitive response-related death. Plant Mol. Biol. 44:321-334.

Hou, S., Yang, Y., and Zhou, J. M. 2009. The multilevel and dynamic interplay between plant and pathogen. Plant Signal. Behav. 4:283-293.

Innes, R. W. 2004. Guarding the goods. New insights into the central alarm system of plants. Plant Physiol. 135:695-701.

Jaillais, Y., Belkhadir, Y., Balsemão-Pires, E., Dangl, J. L., and Chory, J. 2011. Extracellular leucine-rich repeats as a platform for receptor/coreceptor complex formation. Proc. Natl. Acad. Sci. U.S.A. 108:85038507

Jia, Y., McAdams, S. A., Bryan, G. T., Hershey, H. P., and Valent, B. 2000. Direct interaction of resistance gene and avirulence gene products confers rice blast resistance. EMBO (Eur. Mol. Biol. Organ.) J. 19:40044014.

Jiménez-Gómez, J. M., and Maloof, J. N. 2009. Plant research accelerates along the (bio)informatics superhighway: Symposium on plant sensing, response and adaptation to the environment. EMBO (Eur. Mol. Biol. Organ.) Rep. 10:568-572.

Jones, D. A., and Jones, J. D. G. 1997. The role of leucine-rich repeat proteins in plant defences. Adv. Bot. Res. 24:89-167.

Jones, D. A., and Takemoto, D. 2004. Plant innate immunity-direct and indirect recognition of general and specific pathogen-associated molecules. Curr. Opin. Immunol. 16:48-62.

Jones, J. D., and Dangl, J. L. 2006. The plant immune system. Nature 444:323-329.

Karpova, O. V., Zayakina, O. V., Arkhipenko, M. V., Sheval, E. V., Kiselyova, O. I., Poljakov, V. Y., Yaminsky, I. V., Rodionova, N. P., and Atabekov, J. G. 2006. Potato virus $X$ RNA-mediated assembly of single-tailed ternary 'coat protein-RNA-movement protein' complexes. J. Gen. Virol. $87: 2731-2740$.

Kavanagh, T., Goulden, M., Santa Cruz, S., Chapman, S., Barker, I., and Baulcombe, D. 1992. Molecular analysis of a resistance-breaking strain of potato virus X. Virology 189:609-617.

Kohler, A., Rinaldi, C., Duplessis, S., Baucher, M., Geelen, D., Duchaussoy, F., Meyers, B. C., Boerjan, W., and Martin, F. 2008. Genome-wide identification of NBS resistance genes in Populus trichocarpa. Plant Mol. Biol. 66:619-636. 
Kohm, B. A., Goulden, M. G., Gilbert, J. E., Kavanagh, T. A., and Baulcombe, D. C. 1993. A potato virus X resistance gene mediates an induced, nonspecific resistance in protoplasts. Plant Cell 5:913-920.

Labate, J. A., Robertson, L. D., Wu, F., Tanksley, S. D., and Baldo, A. M. 2009. EST, COSII, and arbitrary gene markers give similar estimates of nucleotide diversity in cultivated tomato (Solanum lycopersicum L.). Theor. Appl. Genet. 118:1005-1014.

Løvdal, T., and Lillo, C. 2009. Reference gene selection for quantitative real-time PCR normalization in tomato subjected to nitrogen, cold, and light stress. Anal. Biochem. 387:238-242.

Lukashina, E., Badun, G., Fedorova, N., Ksenofontov, A., Nemykh, M., Serebryakova, M., Mukhamedzhanova, A., Karpova, O., Rodionova, N., Baratova, L., and Dobrov, E. 2009. Tritium planigraphy study of structural alterations in the coat protein of Potato virus $X$ induced by binding of its triple gene block 1 protein to virions. FEBS (Fed. Eur. Biochem. Soc.) J. 276:7006-7015

Lukasik, E., and Takken, F. L. 2009. STANDing strong, resistance proteins instigators of plant defence. Curr. Opin. Plant Biol. 12:427-436.

Lukyanenko, A. N. 1991. Disease resistance in tomato. Pages 99-119 in: Genetic Improvement of Tomato. Vol. 14 of Monographs on Theoretical and Applied Genetics. G. Kalloo, ed. Springer, Berlin.

Mac Dowell, J., and Woffenden, B. J. 2003. Plant disease resistance genes: Recent insights and potential applications. Trends Biotechnol. 21:178183

Mackey, D., Holt, B. F., Wiig, A., and Dangl, J. L. 2002. RIN4 interacts with Pseudomonas syringae type III effector molecules and is required for RPM1-mediated resistance in Arabidopsis. Cell 108:743-754.

Martelli, G. P., Adams, M. J., Kreuze, J. F., and Dolja, V. V. 2007. Family Flexiviridae: A case study in virion and genome plasticity. Annu. Rev. Phytopathol. 45:73-100.

Martí, E., Gisbert, C., Bishop, G. J., Dixon, M. S., and García-Martínez, J. L. 2006. Genetic and physiological characterization of tomato cv. Micro-Tom. J. Exp. Bot. 57:2037-2047.

Martin, G. B., Bogdanove, A. J., and Sessa, G. 2003. Understanding the functions of plant disease resistance proteins. Annu. Rev. Plant Biol. 54:23-61.

Matsukura, C., Aoki, K. A., Fukuda, N., Mizoguchi, T., Asamizu, E., Saito, T., Shibata, D., and Ezura, H. 2008. Comprehensive resources for tomato functional genomics based on the miniature tomato Micro-Tom. Curr. Genomics 9:436-443.

McHale, L., Tan, X., Koehl, P., and Michelmore, R. W. 2006. Plant NBSLRR proteins: Adaptable guards. Genome Biol. 7:212.

Meier, I. 2007. Composition of the plant nuclear envelope: Theme and variations. J. Exp. Bot. 58:27-34.

Meier, I., and Brkljacic, J. 2009a. Adding pieces to the puzzling plant nuclear envelope. Curr. Opin. Plant Biol. 12:752-759.

Meier, I., and Brkljacic, J. 2009b. The nuclear pore and plant development. Curr. Opin. Plant Biol. 12:87-95.

Meissner, R., Jacobson, Y., Melamed, S., Levyatuv, S., Shalev, G., Ashri, A., Elkind, Y., and Levy, A. 1997. A new model system for tomato genetics. Plant J. 12:1465-1472.

Meyers, B. C., Kozik, A., Griego, A., Kuang, H., and Michelmore, R. W. 2003. Genome-wide analysis of NBS-LRR-encoding genes in Arabidopsis. Plant Cell 15:809-834.

Moffett, P., Farnham, G., Peart, J., and Baulcombe, D. C. 2002. Interaction between domains of a plant NBS-LRR protein in disease resistance-related cell death. EMBO (Eur. Mol. Biol. Organ.) J. 21:45114519.

Monosi, B., Wisser, R. J., Pennill, L., and Hulbert, S. H. 2004. Full-genome analysis of resistance gene homologues in rice. Theor. Appl. Genet. 109:1434-1437.

Mucyn, T. S., Clemente, A., Andriotis, V. M., Balmuth, A. L., Oldroyd, G E., Staskawicz, B. J., and Rathjen, J. P. 2006. The tomato NBARC-LRR protein Prf interacts with Pto kinase in vivo to regulate specific plant immunity. Plant Cell 18:2792-2806.

Mueller, L. A., Lankhorst, R. K., Tanksley, S. D., Giovannoni, J. J., White, R., Vrebalov, J., Fei, Z., van Eck, J., Buels, R., Mills, A. A., Menda, N., Tecle, I. Y., Bombarely, A., Stack, S., Royer, S. M., Chang, S. B., Shearer, L. A., Kim, B. D., Jo, S. H., Hur, C. G., Choi, D., Li, C. B., Zhao, J., Jiang, H., Geng, Y., Dai, Y., Fan, H., Chen, J., Lu, F., Shi, J., Sun, S., Chen, J., Yang, X., Lu, C., Chen, M., Cheng, Z., Li, C., Ling, H., Xue, Y., Wang, Y., Seymour, G. B., Bishop, G. J., Bryan, G., Rogers, J., Sims, S., Butcher, S., Buchan, D., Abbott, J., Beasley, H., Nicholson, C., Riddle, C., Humphray, S., McLaren, K., Mathur, S., Vyas, S., Solanke, A. U., Kumar, R., Gupta, V., Sharma, A. K., Khurana, P., Khurana, J. P., Tyagi, A., Sarita, Chowdhury, P., Shridhar, S. Chattopadhyay, D., Pandit, A., Singh, P., Kumar, A., Dixit, R., Singh, A., Praveen, S., Dalal, V., Yadav, M., Ghazi, I. A., Gaikwad, K., Sharma, T. R., Mohapatra, T., Singh, N. K., Szinay, D., de Jong, H., Peters, S., van Staveren, M., Datema, E., Fiers, M. W. E. J., van Ham,
R. C. H. J., Lindhout, P., Philippot, M., Frasse, P., Regad, F., Zouine, M., Bouzayen, M., Asamizu, E., Sato, S., Fukuoka, H., Tabata, S., Shibata, D., Botella, M. A., Perez-Alonso, M., Fernandez-Pedrosa, V., Osorio, S., Mico, A., Granell, A., Zhang, Z., He, J., Huang, S., Du, Y. Qu, D., Liu, L., Liu, D., Wang, J., Ye, Z., Yang, W., Wang, G., Vezzi, A., Todesco, S., Valle, G., Falcone, G., Pietrella, M., Giuliano, G., Grandillo, S., Traini, A., D’Agostino, N., Chiusano, M. L., Ercolano, M., Barone, A., Frusciante, L., Schoof, H., Jöcker, A., Bruggmann, R., Spannagl, M., Mayer, K. X. F., Guigó, R., Camara, F., Rombauts, S., Fawcett, J. A., Van de Peer, Y., Knapp, S., Zamir, D., and Stiekema, W. 2009. A snapshot of the emerging tomato genome sequence. Plant Genome 2:78-92.

Nimchuk, Z., Eulgem, T., Holt, B. F., and Dangl, J. L. 2003. Recognition and response in the plant immune system. Annu. Rev. Genet. 37:579-609.

Noël, L. D., Cagna, G., Stuttmann, J., Wirthmüller, L., Betsuyaku, S., Witte, C. P., Bhat, R., Pochon, N., Colby, T., and Parker, J. E. 2007. Interaction between SGT1 and cytosolic/nuclear HSC70 chaperones regulates Arabidopsis immune responses. Plant Cell 19:4061-4076.

Ozaki, S., Ogata, Y., Suda, K., Kurabayashi, A., Suzuki, T., Yamamoto, N., Iijima, Y., Tsugane, T., Fujii, T., Konishi, C., Inai, S., Bunsupa, S., Yamazaki, M., Shibata, D., and Aoki, K. 2010. Coexpression analysis of tomato genes and experimental verification of coordinated expression of genes found in a functionally enriched coexpression module. DNA Res. 17:105-116.

Pay, A., Resch, K., Frohnmeyer, H., Fejes, E., Nagy, F., and Nick, P. 2002. Plant RanGAPs are localized at the nuclear envelope in interphase and associated with microtubules in mitotic cells. Plant J. 30:699-709.

Peart, J. R., Lu, R., Sadanandom, A., Malcuit, I., Moffett, P., Brice, D. C., Schauser, L., Jaggard, D.A., Xiao, S., Coleman, M. J., Dow, M., Jones, J. D., Shirasu, K., and Baulcombe, D. C. 2002. Ubiquitin ligase-associated protein SGT1 is required for host and nonhost disease resistance in plants. Proc. Natl. Acad. Sci. U.S.A. 99:10865-10869.

Querci, M., van der Vlugt, R., Goldbach, R., and Salazar, L. F. 1993. RNA sequence of potato virus X strain HB. J. Gen. Virol. 74:2251-2255.

Rairdan, G. J., Collier, S. M., Sacco, M. A., Baldwin, T. T., Boettrich, T., and Moffett, P. 2008. The Coiled-coil and nucleotide binding domains of the potato $\mathrm{Rx}$ disease resistance protein function in pathogen recognition and signaling. Plant Cell 20:739-751.

Rathjen, J. P., Chang, J. H., Staskawicz, B. J., and Michelmore, R. W. 1999. Constitutively active Pto induces a Prf-dependent hypersensitive response in the absence of avrPto. EMBO (Eur. Mol. Biol. Organ.) J. 18:3232-3240.

Rep, M., van der Does, H. C., Meijer, M., van Wijk, R., Houterman, P. M. Dekker, H. L., de Koster, C. G., and Cornelissen, B. J. 2004. A small, cysteine-rich protein secreted by Fusarium oxysporum during colonization of xylem vessels is required for I-3-mediated resistance in tomato. Mol. Microbiol. 53:1373-1383.

Rep, M., Meijer, M., Houterman, P. M., van der Does, H. C., and Cornelissen, B. J. 2005. Fusarium oxysporum evades I-3-mediated resistance without altering the matching avirulence gene. Mol. PlantMicrobe Interact. 18:15-23.

Ritter, E., Debener, T., Barone, A., Salamini, F., and Gebhardt, C. 1991. RFLP mapping on potato chromosomes of two genes controlling extreme resistance to Potato virus X (PVX). Mol. Gen. Genet. 227:81-85.

Rong, W., Feng, F., Zhou, J., and He, C. 2010. Effector-triggered innate immunity contributes Arabidopsis resistance to Xanthomonas campestris. Mol. Plant Pathol. 11:783-793.

Sacco, M. A., Mansoor, S., and Moffett, P. 2007. A RanGAP protein physically interacts with the NB-LRR protein Rx, and is required for Rx-mediated viral resistance. Plant J. 52:82-93.

Saito, T., Ariizumi, T., Okabe, Y., Asamizu, E., Hiwasa-Tanase, K., Fukuda, N., Mizoguchi, T., Yamazaki, Y., Aoki, K., and Ezura, H. 2011. TOMATOMA: A novel tomato mutant database distributing Micro-Tom mutant collections. Plant Cell Physiol. 52:283-296.

Shirasawa, K., Asamizu, E., Fukuoka, H., Ohyama, A., Sato, S., Nakamura, Y., Tabata, S., Sasamoto, S., Wada, T., Kishida, Y., Tsuruoka, H., Fujishiro, T., Yamada, M., and Isobe, S. 2010a. An interspecific linkage map of SSR and intronic polymorphism markers in tomato. Theor. Appl. Genet. 121:731-739.

Shirasawa, K., Isobe, S., Hirakawa, H., Asamizu, E., Fukuoka, H., Just, D. Rothan, C., Sasamoto, S., Fujishiro, T., Kishida, Y., Kohara, M., Tsuruoka, H., Wada, T., Nakamura, Y., Sato, S., and Tabata, S. 2010b. SNP discovery and linkage map construction in cultivated tomato. DNA Res. 17:381-391

Shirasu, K. 2009. The HSP90-SGT1 chaperone complex for NLR immune sensors. Annu. Rev. Plant Biol. 60:139-164.

Slootweg, E., Roosien, J., Spiridon, L. N., Petrescu, A. J., Tameling, W., Joosten, M., Pomp, R., van Schaik, C., Dees, R., Borst, J. W., Smant, G., Schots, A., Bakker, J., and Goverse, A. 2010. Nucleocytoplasmic distribution is required for activation of resistance by the potato NB- 
LRR receptor $\mathrm{Rx} 1$ and is balanced by its functional domains. Plant Cell 22:4195-4215.

Tago, K., Tsukahara, F., Naruse, M., Yoshioka, T., and Takano, K. 2004 Regulation of nuclear retention of glucocorticoid receptor by nuclear Hsp90. Mol. Cell. Endocrinol. 213:131-138.

Takahashi, H., Shimizu, A., Arie, T., Rosmalawati, S., Fukushima, S., Kikuchi, M., Hikichi, Y., Kanda, A., Takahashi, A., Kiba, A., Ohnishi, K., Ichinose, Y., Taguchi, F., Yasuda, C., Kodama, M., Egusa, M., Masuta, C., Sawada, H., Shibata, D., Hori, K., and Watanabe, Y. 2005. Catalog of Micro-Tom tomato responses to common fungal, bacterial, and viral pathogens. J. Gen. Plant Pathol. 71:8-22.

Takken, F. L., and Tameling, W. I. 2009. To nibble at plant resistance proteins. Science 324:744-746.

Takken, F. L., Albrecht, M., and Tameling, W. I. 2006. Resistance proteins: Molecular switches of plant defence. Curr. Opin. Plant Biol. 9:383-390.

Tameling, W. I., and Baulcombe, D. C. 2007. Physical association of the NB-LRR resistance protein Rx with a Ran GTPase-activating protein is required for extreme resistance to Potato virus X. Plant Cell 19:16821694.

Tameling, W. I., Elzinga, S. D., Darmin, P. S., Vossen, J. H., Takken, F. L., Haring, M. A., and Cornelissen, B. J. 2002. The tomato $R$ gene products I-2 and MI-1 are functional ATP binding proteins with ATPase activity. Plant Cell 14:2929-2939.

Tameling, W. I., Nooijen, C., Ludwig, N., Boter, M., Slootweg, E., Goverse, A., Shirasu, K., and Joosten, M. H. 2010. RanGAP2 mediates nucleocytoplasmic partitioning of the NB-LRR immune receptor Rx in the Solanaceae, thereby dictating Rx function. Plant Cell 22:4176-4194.

Tamura, M., and Tachida, H. 2011. Evolution of the number of LRRs in plant disease resistance genes. Mol. Genet. Genomics 285:393-402.

Tanksley, S. D. 1993. Mapping polygenes. Annu. Rev. Genet. 27:205-233.

Tozzini, A. C., Ceriani, M. F. Saladrigas, M. V., and Hopp, H. E. 1991. Extreme resistance to infection by potato virus $\mathrm{X}$ in genotypes of wild tuberbearing Solanum species. Potato Res. 34:317-324.

Ueda, H., Yamaguchi, Y., and Sano, H. 2006. Direct interaction between the tobacco mosaic virus helicase domain and the ATP-bound resistance protein, $\mathrm{N}$ factor during the hypersensitive response in tobacco plants.
Plant Mol. Biol. 61:31-45.

Van der Biezen, E. A., and Jones, J. D. 1998. The NB-ARC domain: A novel signalling motif shared by plant resistance gene products and regulators of cell death in animals. Curr. Biol. 8:226-227.

Van der Hoorn, R. A., and Kamoun, S. 2008. From guard to decoy: A new model for perception of plant pathogen effectors. Plant Cell 20:20092017

Van Ooijen, G., van den Burg, H. A., Cornelissen, B. J., and Takken, F. L. 2007. Structure and function of resistance proteins in solanaceous plants. Annu. Rev. Phytopathol. 45:43-72.

Verchot-Lubicz, J., Ye, C. M., and Bamunusinghe, D. 2007. Molecular biology of potexviruses: Recent advances. J. Gen. Virol. 88:1643-1655.

Whitham, S., Dinesh-Kumar, S. P., Choi, D., Hehl, R., Corr, C., and Baker B. 1994. The product of the tobacco mosaic virus resistance gene $\mathrm{N}$ : Similarity to toll and the interleukin-1 receptor. Cell 78:1101-1115.

$\mathrm{Xu}, \mathrm{X}$. M., Meulia, T., and Meier, I. 2007. Anchorage of plant RanGAP to the nuclear envelope involves novel nuclear-pore-associated proteins. Curr. Biol. 17:1157-1163.

Yang, S., Zhang, X., Yue, J. X., Tian, D., and Chen, J. Q. 2008. Recent duplications dominate NBS encoding gene expansion in two woody species. Mol. Genet. Genomics 280:187-198.

Young, N. D. 2000. The genetic architecture of resistance. Curr. Opin. Plant Biol. 3:285-290.

Zayakina, O., Arkhipenko, M., Kozlovsky, S., Nikitin, N., Smirnov, A., Susi, P., Rodionova, N., Karpova, O., and Atabekov, J. 2008. Mutagenic analysis of Potato virus $X$ movement protein (TGBp1) and the coat protein $(\mathrm{CP})$ : In vitro TGBp1-CP binding and viral RNA translation activation. Mol. Plant Pathol. 9:37-44.

Zhang, Y., Goritschnig, S., Dong, X., and Li, X. 2003. A gain-of-function mutation in a plant disease resistance gene leads to constitutive activation of downstream signal transduction pathways in suppressor of npr1-1, constitutive 1. Plant Cell 15:2636-2646.

\section{AUTHOR-RECOMMENDED INTERNET RESOURCE}

Sol genomics network database: www.sgn.cornell.edu 